\title{
Redescription of the argyrolagid Microtragulus bolivianus (Metatheria, Polydolopimorphia, Bonapartheriiformes) based on new remains from Northwestern Argentina
}

\author{
M. Judith Babot and Daniel A. García-López
}

\begin{abstract}
This work is based on new dental, cranial, and postcranial remains of the argyrolagid Microtragulus bolivianus (Metatheria, Polydolopimorphia, Bonapartheriiformes) and dental pieces of Microtragulus sp. coming from late Pliocene-early Pleistocene levels of the Uquía Formation exposed at San Roque, Humahuaca (Jujuy Province, Argentina). They were found in association with amphibians, lizards, birds, rodents, and didelphid marsupials, forming an assemblage probably generated by the trophic activity of owls. Specimens were assigned to M. bolivianus based on the following combination of features: M3 subcircular, with a flexus between the mesiolabial lobe and the metacone, paracone and metacone not differentiated in M4, absence of entoflexid in m1-2 and shallow entoflexid in m3, proportionally large talonid in m4, with a distinguishable distal flexid. Microtragulus bolivianus, initially recorded in Pliocene sediments exposed at the Bolivian Altiplano, was represented only by a mandibular fragment with one incisor and m3-m4. Based on a much more complete sample we present a detailed dental and postcranial description of the species. Since 1904 the family name Argyrolagidae and the generic names Microtragulus and Argyrolagus have been subject of several nomenclatural changes. A revision of these modifications, mainly those occurring in the last 40 years, is also presented. Furthermore, we analyze some mandibular traits of argyrolagids such as the maxillary canal (retrodental canal), a very odd feature present in all the members of the family, which could be related to the passage of a connection between the inferior alveolar and inferior orbital veins, as in some extant mammals.
\end{abstract}

M. Judith Babot. Fundación Miguel Lillo, Miguel Lillo 251, 4000, San Miguel de Tucumán, Tucumán, Argentina; jubabot@gmail.com and CONICET-Consejo Nacional de Investigaciones Científicas y Técnicas, Argentina Daniel A. García-López. CONICET-Consejo Nacional de Investigaciones Científicas y Técnicas, Argentina, Facultad de Ciencias Naturales, Miguel Lillo 205, 4000, San Miguel de Tucumán, Tucumán, Argentina; garcialopez.da@gmail.com, and Instituto Superior de Correlación Geológica-INSUGEO (CONICET)

Babot, M. Judith and García-López, Daniel A. 2016. Redescription of the argyrolagid Microtragulus bolivianus (Metatheria, Polydolopimorphia, Bonapartheriiformes) based on new remains from Northwestern Argentina. Palaeontologia Electronica 19.2.23A: 1-23

palaeo-electronica.org/content/2016/1481-argyrolagid-from-northwestern-argentina

Copyright: @ July 2016 Society of Vertebrate Paleontology. This is an open access article distributed under the terms of the Creative Commons Attribution License, which permits unrestricted use, distribution, and reproduction in any medium, provided the original author and source are credited.

creativecommons.org/licenses/by/4.0/ 
Keywords: Argyrolagidae; Bonapartheriiformes; Marsupialia; Uquía Formation; Umala Formation; Marplatan SALMA

Submission: 3 August 2015 Acceptance: 2 May 2016

\section{INTRODUCTION}

Argyrolagidae is an odd group of small fossil metatherians, which inhabited South America during the Cenozoic. Its temporal range extends from the late Oligocene (Deseadan South American Land Mammal Age [SALMA]) to the early Pleistocene (Marplatan SALMA, Sanandresian subage). The family is only known from Argentina and Bolivia, although the closely related argyrolagoid Khlonia is also present in Chile (Ameghino, 1904; Kraglievich, 1931; Simpson, 1970a, 1970b; Hoffstetter and Villarroel, 1974; Wolff, 1984; Villarroel and Marshall, 1988; Goin et al., 2000, 2010; Carlini et al., 2007). Some of the most remarkable features of the group are the presence of an elongated snout, large orbits, very large palatal vacuities and wide incisive foramina, inflated tympanic bullae, procumbent lower incisors, hypsodont and highly modified molars, short, and high mandibular body, low and short coronoid process, mandibular notch long, and maxillary canal present (retrodental canal sensu Hofftsetter and Villarroel, 1974). The postcranial skeleton also shows several peculiarities such as the shortening of the forelimb, the lengthening of the tibia-fibula and metatarsals, and the reduced number of elements in the posterior autopodium, specifically the metatarsals and phalanges, all these features associated with a bipedal stance and leaping locomotor habits (Simpson, 1970a).

For more than a century, several authors studied the taxonomy, anatomy, phylogeny, and paleobiology of the group (Ameghino, 1904, 1906; Rovereto, 1914; Kraglievich, 1931; Rusconi, 1933, 1936; Simpson, 1970a, 1970b; Hoffstetter and Villarroel, 1974; Wolff, 1984; Villarroel and Marshall, 1988; Sánchez-Villagra and Kay, 1997; Goin et al., 2000; Sánchez-Villagra et al., 2000; Sánchez-Villagra, 2001; Abello et al., 2002; Carlini et al., 2007; Zimicz, 2011; Goin and Abello, 2013). There are currently five genera and 12 recognized species. Two genera are monospecific (Hondalagus Villarroel and Marshall, 1988 and Anargyrolagus Carlini, Pascual, and Goin, 2007) while Proargyrolagus Wolff, 1984, Argyrolagus Ameghino, 1904, and Microtragulus Ameghino, 1904 are represented by two or more species (see Table 1).
Microtragulus is the most widely distributed argyrolagid, including records in central and northwestern Argentina and the Bolivian Plateau. The current geographical record indicates a disjunct distributional pattern comprising coastal as well as highland areas. Microtragulus reigi is the only species known from lowland areas (the existence of $M$. argentinus remains questionable; see Discussion) and $M$. catamarcensis and $M$. bolivianus are restricted to mid and high altitudes (García-López and Babot, 2015). The oldest record of the genus, a mandibular fragment of $M$. catamarcensis, is known from ?early Miocene levels exposed at Mendoza Province, Argentina (see Garrido et al. [2014] and García-López and Babot [2015]), and the more recent records are known from the late Pliocene-early Pleistocene ( $M$. bolivianus; Marplatan SALMA, probably Vorohuean subage; Ortiz et al., 2012) and early Pleistocene (M. reigi; Marpla$\tan$ SALMA, Sanandresian subage; Cione and Tonni, 2005; Cione et al., 2015).

The genus was initially defined based on the morphology of its lower molars (Simpson, 1970a), but additional characters of the upper dentition have been recently described for this taxon (García-López and Babot, 2015). The dental features that define Microtragulus are the presence of a distinct ectoflexid (labial groove) separating the trigonid from the talonid and absent or vestigial entoflexid (lingual groove) in $\mathrm{m} 1$, trigonid with a dominant metaconid, lower ectostylid and protoconid pointing mesiolabially and separated from the ectostylid by a groove (in $\mathrm{m} 1$ and/or $\mathrm{m} 2$ ), reduced talonid with a distinctive tongue-like hypoconid in $\mathrm{m} 1-2$, well-developed entoconid, and hypoconulid absent or vestigial, and reduced $\mathrm{m} 4$, both in length and width, bearing a vestigial talonid separated from the trigonid by ectoflexid and entoflexid. Regarding the upper dentition, the distinctive features include a reduced StE in M1, poorly-developed paracone coalescent with metacone, reduced mesiolabial lobe in M2 and M3, and convex labial outline, particularly in M2 (García-López and Babot, 2015).

Microtragulus bolivianus is the most northern species of the genus. It was found by Hoffstetter and Villarroel (1974) in levels of the Umala Formation exposed at the locality of Viscachani (Bolivia; 
TABLE 1. List of the genera and species included in the Family Argyrolagidae and their temporal and geographic distribution. Abbreviations: AR, Argentina; BO, Bolivia.

\begin{tabular}{|c|c|c|c|}
\hline Species & Temporal distribution & Geographic distribution & References \\
\hline $\begin{array}{l}\text { Proargyrolagus bolivianus Wolf, } \\
1984\end{array}$ & Late Oligocene (Deseadan) & Salla-Luribay Basin (BO) & $\begin{array}{l}\text { Wolf (1984); Sánchez- } \\
\text { Villagra and Kay (1997) }\end{array}$ \\
\hline $\begin{array}{l}\text { Proargyrolagus argentinus Goin } \\
\text { and Abello, } 2013\end{array}$ & $\begin{array}{l}\text { Early Miocene } \\
\text { (Colhuehuapian) }\end{array}$ & $\begin{array}{l}\text { Puesto Almendra, Chubut } \\
\text { (AR) }\end{array}$ & Goin and Abello (2013) \\
\hline $\begin{array}{l}\text { Anargyrolagus primus Carlini, } \\
\text { Pascual, and Goin } 2007\end{array}$ & $\begin{array}{l}\text { Early Miocene } \\
\text { (Colhuehuapian) }\end{array}$ & $\begin{array}{l}\text { Lower Chubut River valley, } \\
\text { Chubut (AR) }\end{array}$ & $\begin{array}{l}\text { Carlini et al. (2007); Goin and } \\
\text { Abello (2013) }\end{array}$ \\
\hline $\begin{array}{l}\text { Hondalagus altiplanensis } \\
\text { Villarroel and Marshall, } 1988\end{array}$ & Middle Miocene (Laventan) & Quebrada Honda (BO) & $\begin{array}{l}\text { Villarroel and Marshall } \\
\text { (1988); Sánchez-Villagra et } \\
\text { al. (2000) }\end{array}$ \\
\hline $\begin{array}{l}\text { Microtragulus argentinus } \\
\text { Ameghino, } 1904\end{array}$ & $\begin{array}{l}\text { ?Early Pliocene } \\
\text { (Montehermosan) }\end{array}$ & $\begin{array}{l}\text { Monte Hermoso, Buenos } \\
\text { Aires (AR) }\end{array}$ & $\begin{array}{l}\text { Ameghino (1904); Simpson } \\
(1970 a) \text {; Tomassini et al. } \\
(2013)\end{array}$ \\
\hline $\begin{array}{l}\text { M. catamarcensis (Kraglievich, } \\
\text { 1931) }\end{array}$ & $\begin{array}{l}\text { ?Early Miocene - Early } \\
\text { Pliocene }\end{array}$ & $\begin{array}{l}25 \text { de Mayo, Mendoza (AR) } \\
\text { ?Andalhuala, Catamarca } \\
\text { (AR) }\end{array}$ & $\begin{array}{l}\text { Kraglievich (1931); Simpson } \\
\text { (1970a); Garrido et al. } \\
\text { (2014); García-López and } \\
\text { Babot (2015) }\end{array}$ \\
\hline Microtragulus sp. & ?Late Miocene & North of Tucumán (AR) & $\begin{array}{l}\text { García-López and Babot } \\
\text { (2015) }\end{array}$ \\
\hline M. reigi Simpson, 1970a & $\begin{array}{l}\text { Middle Pliocene - Early } \\
\text { Pleistocene; Chapadmalan - } \\
\text { Marplatan }\end{array}$ & $\begin{array}{l}\text { Punta San Andrés, Buenos } \\
\text { Aires (AR) }\end{array}$ & $\begin{array}{l}\text { Simpson (1970a); Cione and } \\
\text { Tonni (2005) }\end{array}$ \\
\hline $\begin{array}{l}\text { M. bolivianus Hoffstetter and } \\
\text { Villarroel, } 1974\end{array}$ & $\begin{array}{l}\text { ?Early Pliocene - Early } \\
\text { Pleistocene } \\
\text { Montehermosan - Marplatan }\end{array}$ & $\begin{array}{l}\text { Vizcachani (BO) } \\
\text { San Roque, Jujuy (AR) }\end{array}$ & $\begin{array}{l}\text { Hoffstetter and Villarroel } \\
\text { (1974); Ortiz et al. (2012) }\end{array}$ \\
\hline $\begin{array}{l}\text { Argyrolagus palmeri Ameghino, } \\
1904\end{array}$ & $\begin{array}{l}\text { Early Pliocene; } \\
\text { Montehermosan }\end{array}$ & $\begin{array}{l}\text { Monte Hermoso, Buenos } \\
\text { Aires (AR) }\end{array}$ & $\begin{array}{l}\text { Ameghino (1904); Tomassini } \\
\text { et al. (2013) }\end{array}$ \\
\hline A. scagliai Simpson, 1970a & $\begin{array}{l}\text { Middle Pliocene; } \\
\text { Chapadmalalan }\end{array}$ & Miramar, Buenos Aires (AR) & Simpson (1970a) \\
\hline A. parodii Rusconii, 1933 & $\begin{array}{l}\text { Middle Pliocene; } \\
\text { Chapadmalalan }\end{array}$ & $\begin{array}{l}\text { Chapadmalal, Buenos Aires } \\
\text { (AR) }\end{array}$ & $\begin{array}{l}\text { Rusconi (1933); Simpson } \\
(1970 a, b)\end{array}$ \\
\hline $\begin{array}{l}\text { A. rusconii (Goin, Montalvo, and } \\
\text { Visconti, 2000) }\end{array}$ & Late Miocene & Bajo Giuliani, La Pampa (AR) & $\begin{array}{l}\text { Goin et al. (2000); García- } \\
\text { López and Babot (2015) }\end{array}$ \\
\hline Argyrolagus sp. & ?Late Miocene & Caleufú, La Pampa (AR) & Abello et al. (2002) \\
\hline
\end{tabular}

Pliocene levels dated between 5.3-2.9 Ma [Marshall et al., 1992; MacFadden et al., 1994]) and described on the basis of scarce remains (a right incomplete mandible preserving only one incisor and m3-4). In this contribution, we present new materials of $M$. bolivianus including dental, mandibular, and postcranial elements. The materials are part of a microvertebrate fossil assemblage, probably produced by the activity of predatory birds, recovered in sediments of the Uquía Formation cropping out in the locality of San Roque, $2 \mathrm{~km}$ south of Humahuaca town, Jujuy Province, northwestern Argentina (Figure 1.1-3). Based on the fossil rodent assemblage Ortiz et al. (2012) suggested that xeric palaeoenvironmental conditions would have prevailed in the region by the end of the Pliocene. The presence of the argyrolagid
Microtragulus, for which adaptations to arid environments were inferred on the basis of their morphological similarity with kangaroo rats, would reinforce this hypothesis (Ortiz et al., 2012).

In this work we provide detailed anatomical descriptions, comparisons, and a revised diagnosis of the species, which was poorly known until now. Additionally, we present an updated revision of the nomenclatural changes suffered by the taxonomic name Argyrolagidae, and examine some particular traits of the dentary of the group.

Institutional abbreviations. GHUNLPam, Facultad de Ciencias Exactas y Naturales de la Universidad Nacional de La Pampa, La Pampa, Argentina; JUY-P, Museo de Geología, Mineralogía y Paleontología, Instituto de Geología y Minería, Universidad Nacional de Jujuy, San Salvador de Jujuy, 


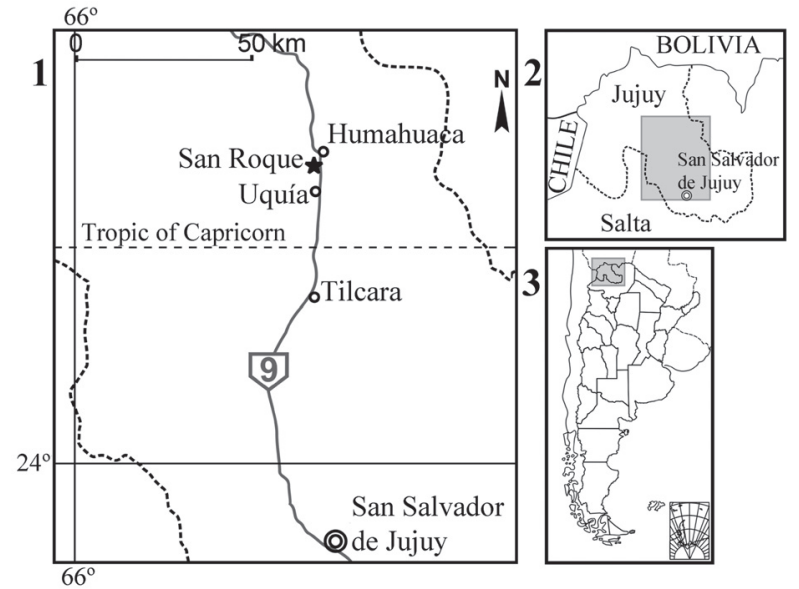

FIGURE 1. 1. Location map of the fossiliferous levels of the Uquía Formation exposed at San Roque, Humahuaca (Jujuy Province, Argentina). Relative location of the prospected area in: 2, Jujuy Province; and 3, Northwestern Argentina. Modified from Ortiz et al. (2012).

Argentina; MACN, Museo Argentino de Ciencias Naturales "Bernardino Rivadavia", Buenos Aires, Argentina; MLP, Museo de La Plata, Buenos Aires, Argentina; MMP, Museo Municipal de Ciencias Naturales "Lorenzo Scaglia", Mar del Plata, Buenos Aires, Argentina; MNHN-BOL-V, Museo de Historia Natural, Colección Paleontología de Vertebrados, La Paz, Bolivia; MPEF-PV, Museo Paleontológico "Egidio Feruglio", Sección Paleontología de Vertebrados, Trelew, Argentina; PVL, Colección Paleontología de Vertebrados Lillo, Instituto Miguel Lillo, Tucumán, Argentina.

Anatomical abbreviations. $\mathrm{M} / \mathrm{m}$, upper/lower molar; P/p, upper/ lower premolar; St, stylar cusp.

\section{MATERIALS AND METHODS}

The nomenclature of molar cusps follows the proposal of Goin et al. (2010) and Goin and Abello (2013) who analyzed the changes in molar morphology from Praedens and Klohnia (as basal Argyrolagoidea) to Proargyrolagus and Anargyrolagus. The arrangement of molar cusps in Microtragulus bolivianus (Figure 2) is based on this hypothesis and in García-López and Babot (2015). Cusp names are used as if they were actually present, although according to the condition of typical euhypsont teeth, the cusped surface is quickly worn away after tooth eruption (sidewall hypsodonty sensu Koenigswald, 2011). Their relative position is inferred by the occlusal relief and tooth outline. The designation of the first lower incisor as i1 follows Goin and Abello (2013). Up to now, there is no supporting evidence for Hershkovitz (1995) scheme in Argyrolagidae and hence, the identity of incisors is still under discussion (e.g., Sánchez-Villagra and Kay, 1997; Sánchez-Villagra, 2001).

We assume that in Microtragulus bolivianus the premolar immediately anterior to the first molar is the third premolar, based on basal members of the group that preserve the complete dental series (Proargyrogalus and Anargyrolagus; Sánchez Villagra et al. [2000]; Carlini et al. [2007]; Goin and Abello [2013]). The anatomical terms used for crania and mandibles follow Wible $(2003,2007)$. The postcranial description is based on general anatomical contributions (Nomina Anatomica Veterinaria; Schaller, 1992) and specific works related with metatherian morphology (de Muizon, 1998; Szalay, 1994).

\section{SYSTEMATIC PALEONTOLOGY}

Infraclass MARSUPIALIA Illiger, 1811

Order POLYDOLOPIMORPHIA Ameghino, 1897

Suborder BONAPARTHERIIFORMES Goin and Candela, 2004

Superfamily ARGYROLAGOIDEA Ameghino, 1904

Family ARGYROLAGIDAE Ameghino, 1904

Genus MICROTRAGULUS Ameghino, 1904

Type Species. Microtragulus argentinus Ameghino, 1904 , by original designation.

Microtragulus bolivianus Hoffstetter and Villarroel, 1974

Figure 2, Figure 3, Figure 4, Figure 5, Figure 6, Figure 7

Holotype. MNHN-BOL-V-011707 (= GB-0001), right mandibular fragment with i1 and m3-m4 (GB refers to the currently nonexistent GEOBOL [Servicio Geológico Boliviano] collection).

Referred Material. JUY-P-0065, fragment of right maxilla with M3-M4; JUY-P 50, edentulous fragment of right maxilla preserving the zygomatic process; JUY-P-0066, right mandibular body with i1, alveoli of i2 and p3, and complete m1-4; JUY-P0067, right mandibular body with complete i1 and $\mathrm{i} 2$, alveolus of $\mathrm{p} 3$, and complete m1-4; JUY-P0068, anterior fragment of right mandibular body with i1 and alveoli of i2 and p3; JUY-P-0069, almost complete right humerus except for the proximal third; JUY-P-0070, almost complete left humerus except for the proximal third; JUY-P0071, distal half of left humerus; JUY-P-0072, distal end of right humerus; JUY-P 59, proximal half of right ulna; JUY-P 60, proximal half of left ulna; JUY$P$ 61, proximal fragment of radius; JUY-P 52, right proximal epiphysis and right distal end of tibiofibula; JUY-P-0073, complete left calcaneus;JUY-P- 

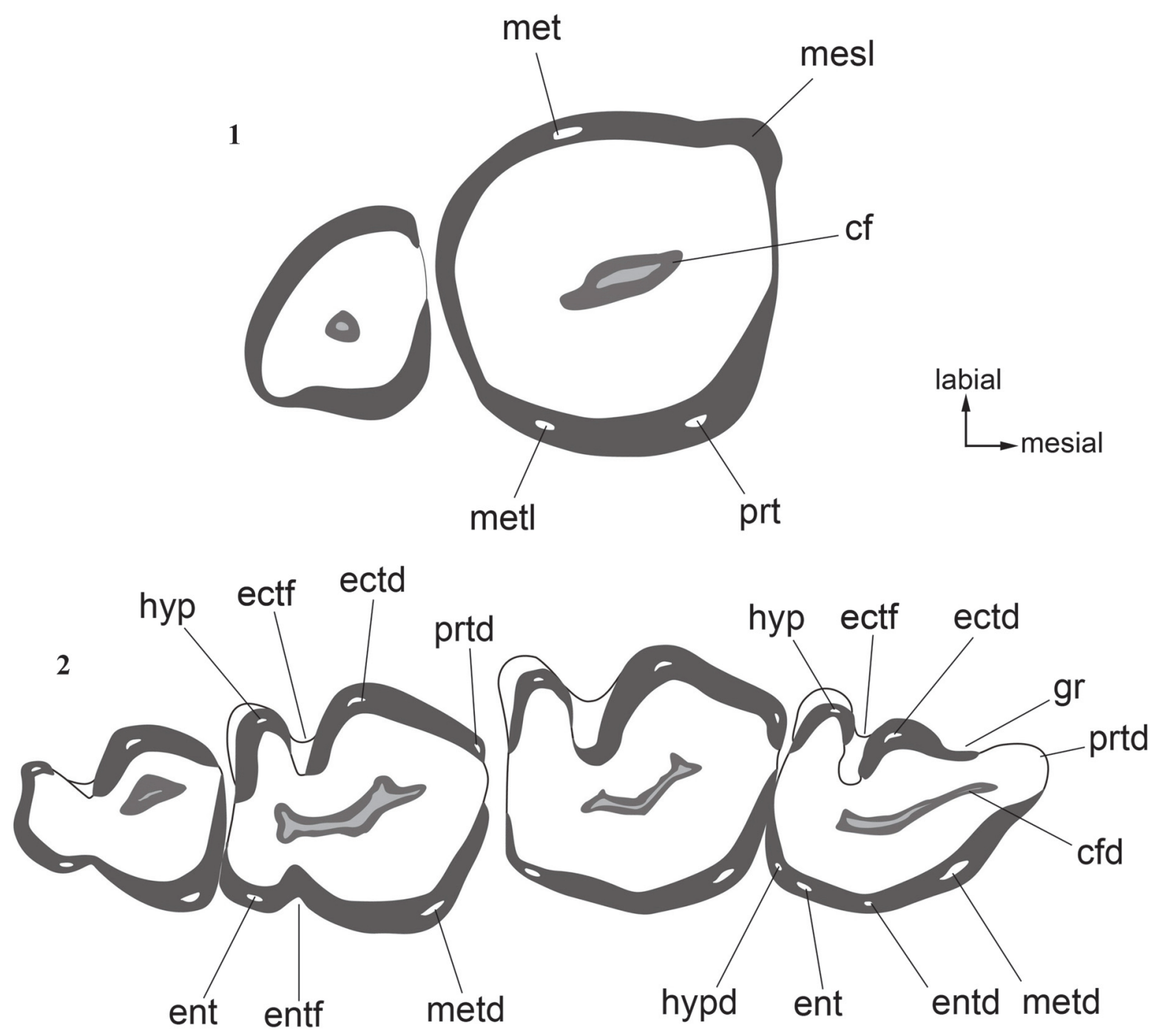

FIGURE 2. Line drawings (occlusal view) of Microtragulus bolivianus showing the anatomical nomenclature used in the text. 1. Right M3-4. 2. Right m1-4 (image reflected). Abbreviations: cf, central fossa; cfd, central fossid; ectf, ectoflexid; ectd, ectostylid; ent, entoconid; entd, entostylid?; entf, entoflexid; gr, groove; hyp, hypoconid; hypd, hypoconulid; mesl, mesiolabial lobe; met, metacone; metd, metaconid; metl, metaconule; prt, protocone; prtd, protoconid.

0074, body of left calcaneus; JUY-P-0075, right astragalus; JUY-P 55, complete right metatarsal III; JUY-P 56, lot containing proximal and distal portions of right metatarsal IV (not associated); JUY-P 57 , distal portion of left metatarsal IV; JUY-P 58, lot containing three ungueal phalanges.

Range and Occurrence. The holotype comes from Viscachani, $94 \mathrm{~km}$ SE of La Paz, Bolivia; Umala Formation (Pliocene levels dated between 5.3-2.9 Ma [Marshall et al., 1992; MacFadden et al., 1994]). The materials studied herein come from San Roque (26 14' 32" S, 65² 21' 55” W; 2940 m), $4.4 \mathrm{~km}$ SSW of Humahuaca town, Humahuaca Department, Jujuy Province, Argentina; Uquía For- mation (late Pliocene-early Pleistocene; Marplatan SALMA, probably Vorohuan subage; Ortiz et al., 2012).

Emended Diagnosis. Microtragulus bolivianus differs from Proargyrolagus by the presence of euhypsodont teeth, simplified occlusal structure, and reduced dental formula (which is also a difference with Hondalagus and Anargyrolagus). Additionally, $M$. bolivianus differs from the species of Hondalagus, Anargyrolagus, and Argyrolagus by the following combined features: M3 subcircular in outline and with a single labial cusp (metacone); M4 proportionally smaller than M3 and without differentiated cuspidal relief; lower molars with talonid 

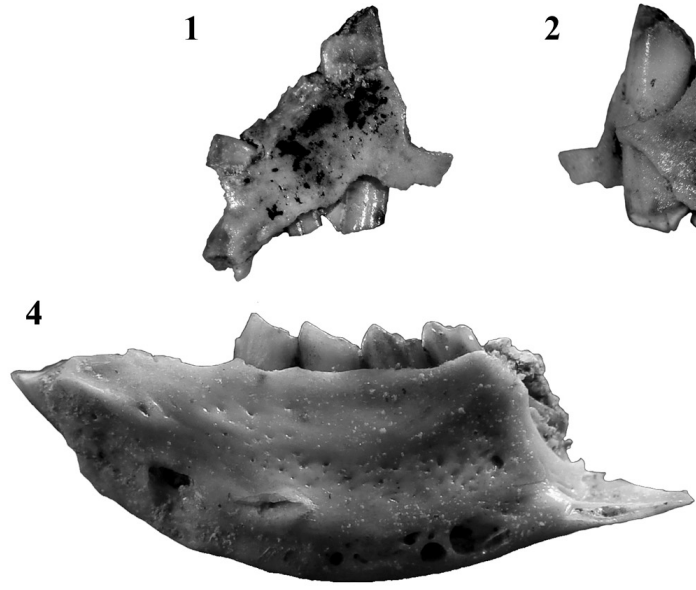

6

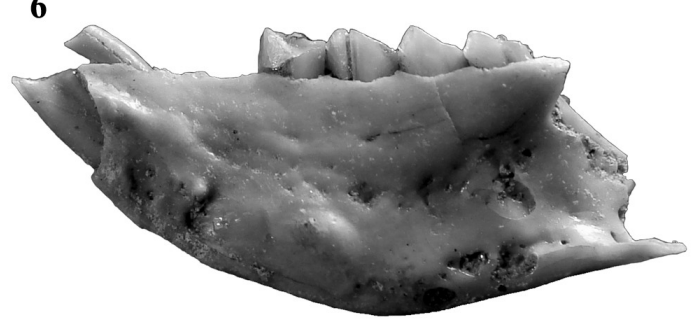

8

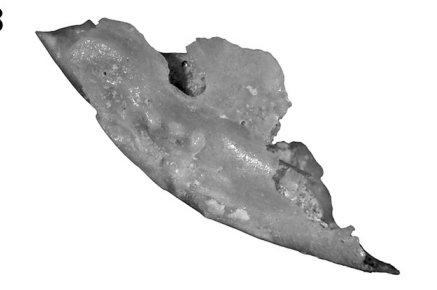

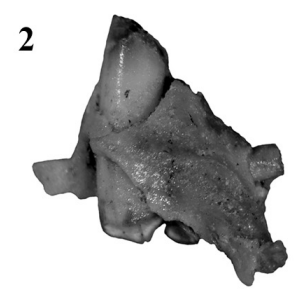

3

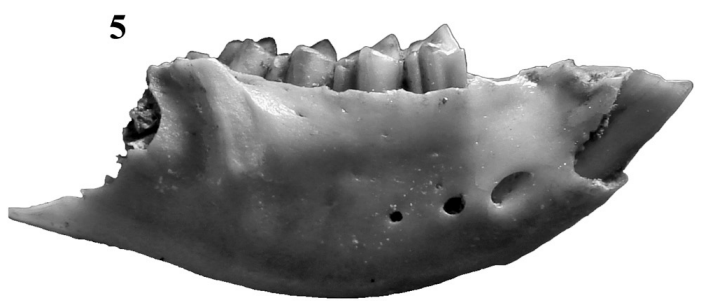

7

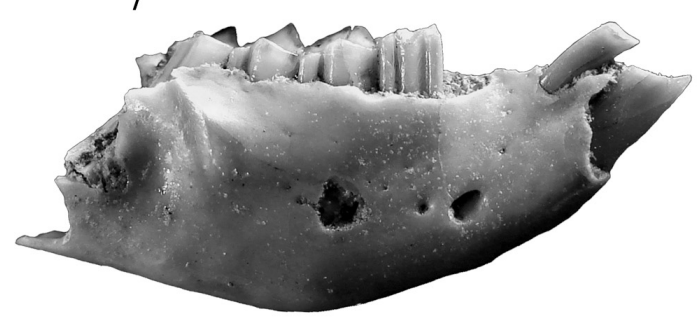

9

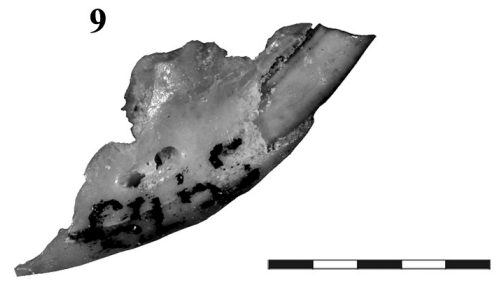

FIGURE 3. Microtragulus bolivianus. 1-3. JUY-P-0065, fragment of right maxilla with M3-M4 in: 1, lateral; 2, medial; and 3, occlusal views. 4-5. JUY-P-0066, right mandibular body with i1, alveoli of i2 and p3, and complete m1-4 in: 4, medial; and 5, lateral views. 6-7. JUY-P-0067, right mandibular body with complete i1 and i2, alveolus of p3, and complete m1-4 in: 6, medial; and 7, lateral views. 8-9. JUY-P-0068, anterior fragment of right mandibular body with i1 and alveoli of i2 and p3 in: 8, medial; and 9, lateral views. Scale bar equals $5 \mathrm{~mm}$.

proportionally shorter than the trigonid, reduced or absent entoflexid; and proportionally smaller $\mathrm{m} 4$. Within Microtragulus, M. bolivianus differs from $M$. reigi by the absence of an entoflexid in $\mathrm{m} 2$, and a shallower entoflexid in $\mathrm{m} 3$; and from $M$. catamarcensis by a proportionally larger $\mathrm{m} 4$ and the presence of a well-marked entoflexid in $\mathrm{m} 3$.

\section{Description}

Maxilla. This bone is represented by two poorly preserved fragments characterized by the presence of several sulci, crests, and foramina (Figure 3.1-3). A deep sulcus is present in the medial side above M4; this sulcus becomes progressively shallower towards the anterior side, and its trajectory matches with the infraorbital canal for the passage of the maxillary nerve (a derivate of the maxillary branch of the trigeminal nerve) and accompanying vessels. This condition is inferred from the observation of the specimen GHUNLPam 8549 (holotype of Argyrolagus rusconii), which preserves the infraorbital foramen connected to a medial sulcus of the maxilla. Other specimen referred to Microtragulus sp. (PVL 6594; García-López and Babot, 2015), shows similar structures. Given this arrangement, we infer that a proper infraorbital canal is absent, being replaced by a sulcus (corresponding to the medial wall of the canal) connected anteriorly to a foramen piercing the maxilla anterior to the orbit. This modified condition is probably 
1
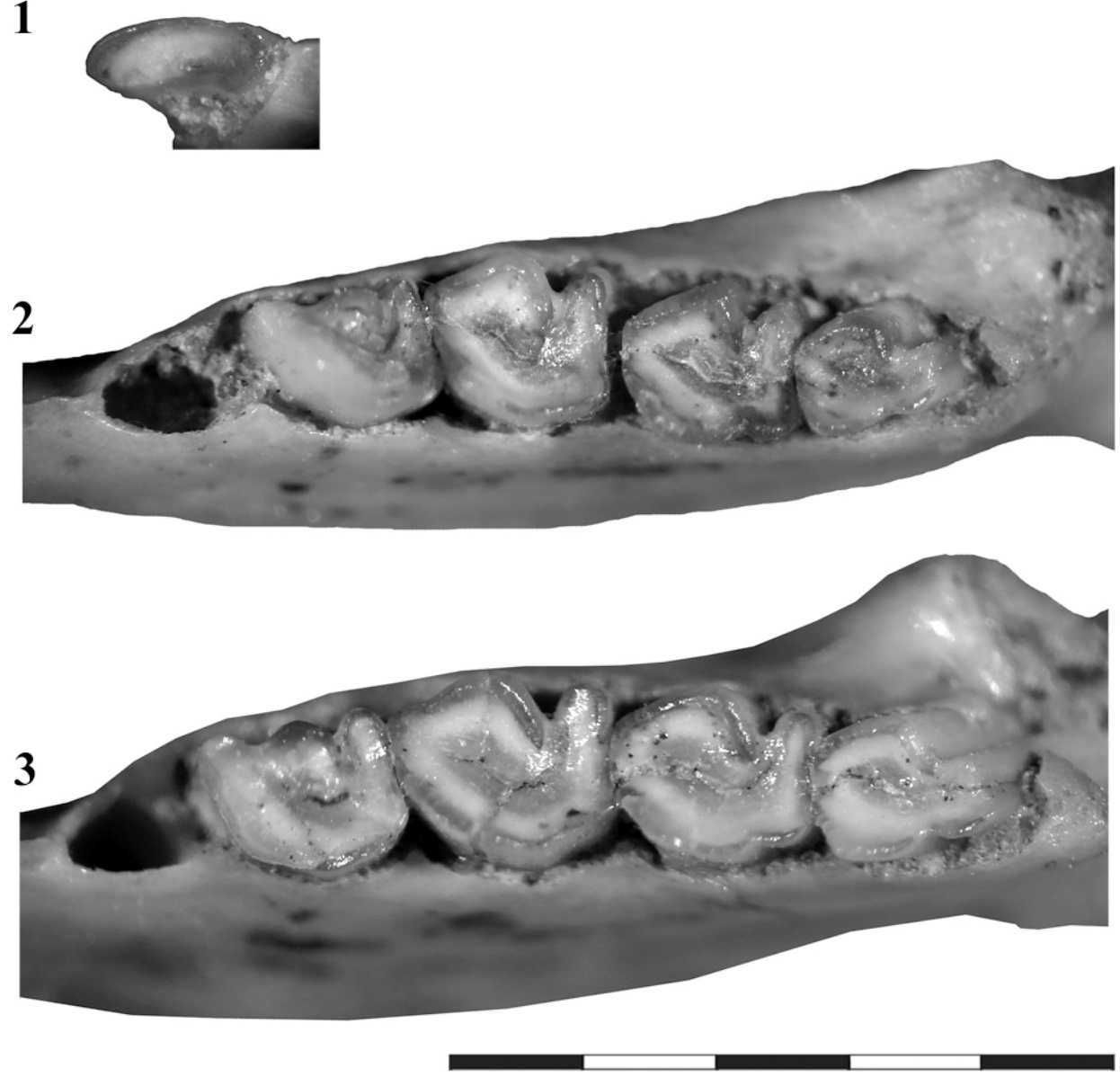

FIGURE 4. Microtragulus bolivianus, right lower dentition in occlusal view. 1. JUY-P-0066, detail of i1. 2. JUY-P-0066, $\mathrm{m} 1-4$. 3. JUY-P-0067, m1-4. Scale bar equals $5 \mathrm{~mm}$.

related to the great development of the palatal vacuities typical of this family.

The specimen preserving the zygomatic process (JUY-P 50) probably corresponds to a juvenile individual, judging by the posterior position of the process (above the alveolus of the last present molariform, which is very large). This would indicate that M4, which is the smallest molar, was not yet fully erupted at the time of death of the individual.

Mandible. The mandibular body is short and high and strongly convex ventrally. The point of maximum height is located at the level of $\mathrm{m} 2$ (Figure 3.4-7); in the labial side, it measures $5.65 \mathrm{~mm}$ in JUY-P-0067 and $4.94 \mathrm{~mm}$ in JUY-P-0066.

In lateral view the body exhibits the mental foramina. In JUY-P-0066 there are three foramina, which are progressively smaller toward the posterior side; the first one is located at the level of p3. The second one is placed at the level of the mesial border of $\mathrm{m} 1$, and the third opening is located at the level of the mesial border of $\mathrm{m} 2$ (Figure 3.5). Only two foramina are visible in JUY-P-0067, although the surface where the third foramen should be is actually broken (Figure 3.7). These openings present the same location than the first and second apertures in JUY-P-0066. Nevertheless, the second foramen is proportionally smaller in this case. The specimen JUY-P-0068 (Figure 3.9) shows a different arrangement: the two preserved foramina open together inside a larger aperture (feature also present in Proargyrolagus bolivianus; Wolf, 1984). Other apertures are several tiny vascular openings scattered all over the lateral surface of the mandibular body.

The lateral side of the mandibular body also preserves a blunt but conspicuous coronoid crest. This structure projects anteroventrally towards the level of the anterior half of $\mathrm{m} 4$. 
1

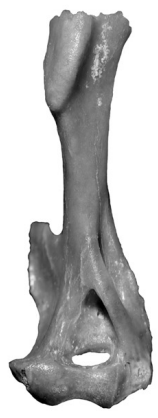

5

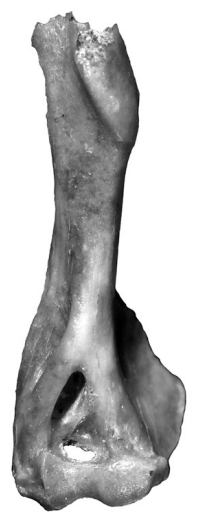

2

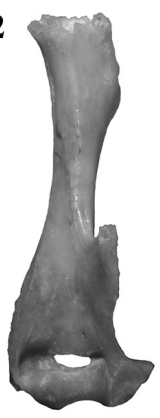

6

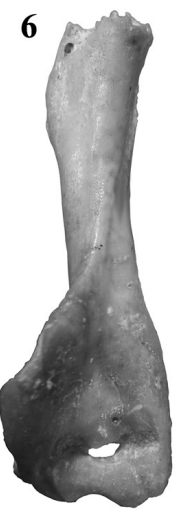

10

9

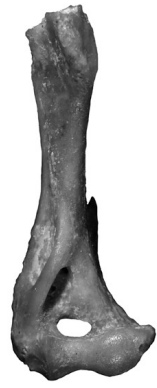

3
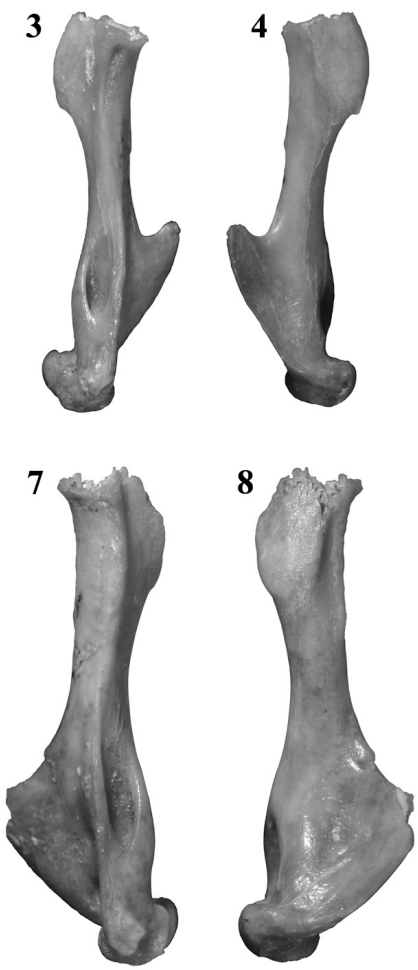

11

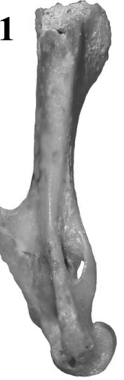

12
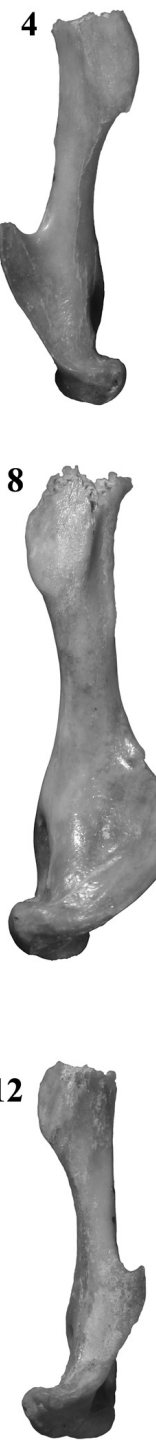

8
15
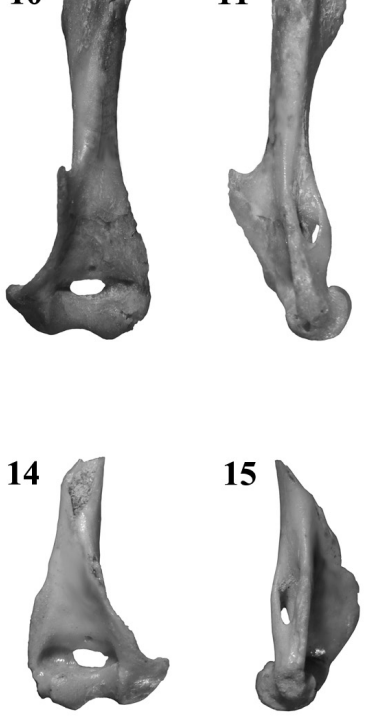

16

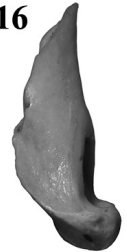

20

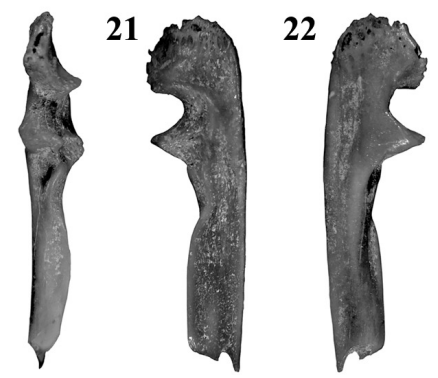

24

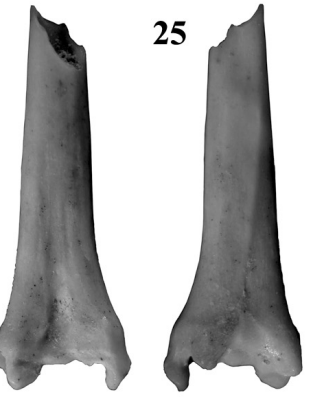

23

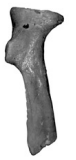

17

18

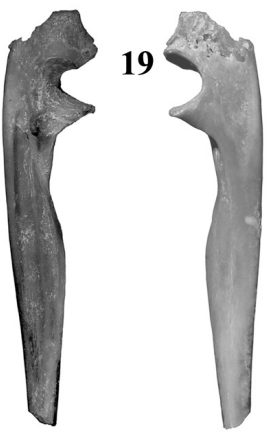

13

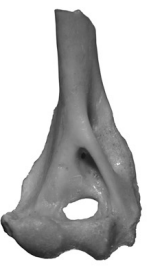

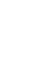


1

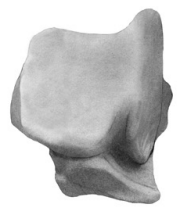

6

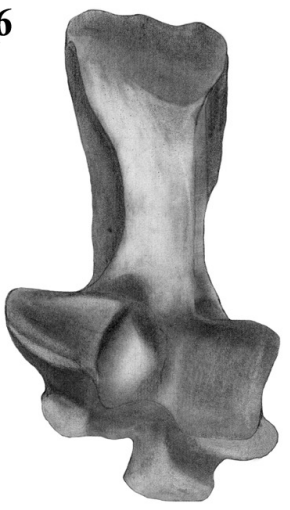

2

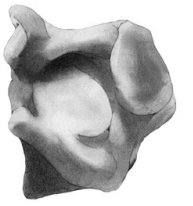

7

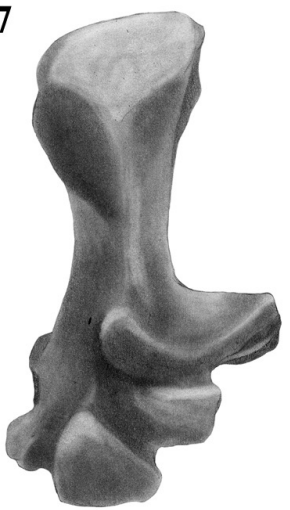

3

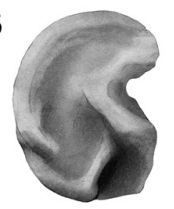

8

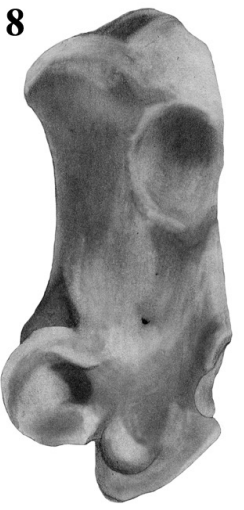

4

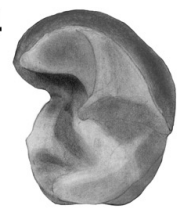

9

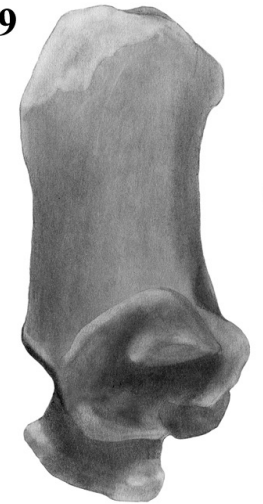

5

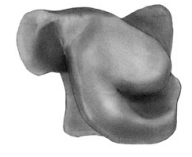

10

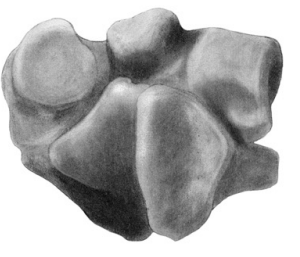

FIGURE 6. Microtragulus bolivianus, astragalus and calcaneus. 1-5. JUY-P-0075, complete right astragalus in: 1 , dorsal; 2, plantar; 3, medial; 4, lateral; and 5, distal views. 6-10. JUY-P-0073, complete left calcaneus in: 6, dorsal; 7, plantar; 8, medial; 9, lateral; and 10, distal views. Scale bar equals $5 \mathrm{~mm}$.

In medial view, the mandible shows an unfused symphysis, the borders of which are not well defined. However, the surface is easily recognized by the presence of several shallow depressions and low tubercles. It extends to the level of the anterior portion of $\mathrm{m} 2$. Both specimens JUY-P0066 and JUY-P-0067 bear several tiny nutritious foramina and fenestrations towards the posteroventral portion of the body (Figure $3.4,6$ ). The angular process is partially preserved; its anterior end is located at the level of the talonid of $\mathrm{m} 4$. The visible portion of this process indicates that it was strongly inflected forming a well-developed concavity facing upwards, as in other argyrolagids (Rusconi, 1933; Simpson, 1970a; Sánchez-Villagra et al., 2000). Two foramina are visible above the process: the dorsal one is the proper mandibular foramen and the aperture located immediately below is interpreted here as an accessory opening of this canal. These secondary openings are also present in the holotype of Microtragulus bolivianus as well as in other argyrolagids. The maxillary canal (see Discussion) is not preserved in the specimens recovered from Uquía Formation but is clearly present in the holotype of $M$. bolivianus (Hoffstetter and Villarroel, 1974).

Dentition. The dentition is euhypsodont and deeply implanted in the maxilla and dentary. The teeth are prismatic, with central dentine surrounded by a layer of enamel. The teeth are also partially surrounded by a thin layer of cementum that thickens in the area of the sulci. All the recovered dental pieces (except the only i2 of the sample studied herein) show a central fossa/fossid. This structure is particularly conspicuous in i1, where the layer of enamel surrounding the inner cavity is clearly present (Figure 4.1). This feature, described for Hondalagus (Villarroel and Marshall, 1988), is also present in Argyrolagus (Simpson, 1970b) and Microtragulus (García-López and Babot, 2015), and probably in Anargyrolagus MPEF-PV 5291.

Upper dentition. M3 is sub-quadrangular (Figures $2.1,3.3)$ and larger than $\mathrm{M} 4(\mathrm{~L}=1.51 \mathrm{~mm}$ and $\mathrm{W}=1.41 \mathrm{~mm})$. The intraalveolar portion of the crown is slightly curved, vertically implanted, and divergent with respect to the intraalveolar portion of M4. The layer of enamel is continuous, although it is thinner in the mesiolabial area. The labial side is clearly higher than the lingual one, which is about the same level of the alveolar border. In the labial edge there is a poorly developed mesiolabial lobe and a distal elevation that we interpret here as the metacone (metacone + StD after Goin and Abello, 2013). The lingual side is rounded and bears the protocone and the metaconule, which is very 
1

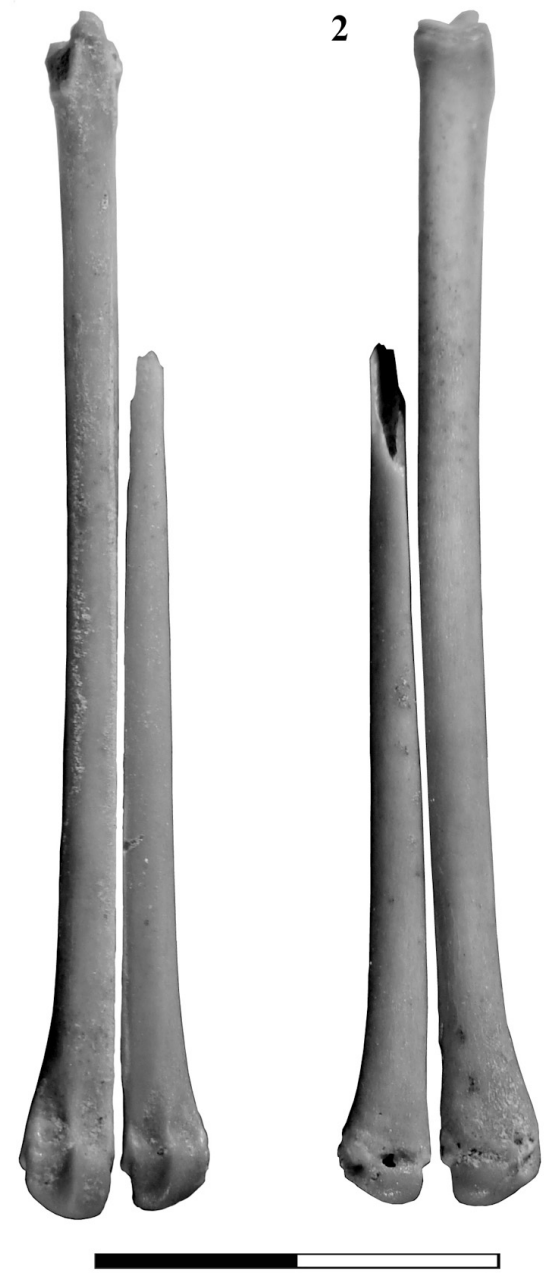

3

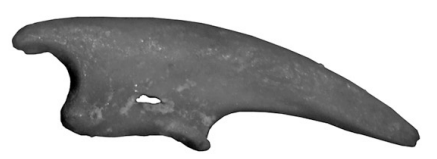

4

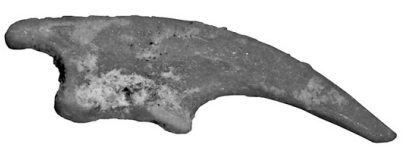

5

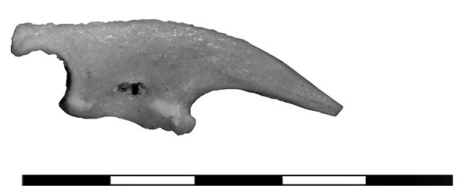

FIGURE 7. Microtragulus bolivianus, metatarsal III and IV and phalanges. JUY-P 55, complete right metatarsal III and JUY-P 56, distal portion of right metatarsal IV (not associated) in: 1, anterior; and 2, posterior views. Scale bar equals $10 \mathrm{~mm}$. 3-5. JUY-P 58, ungual phalanges in lateral view. Scale bar equals $5 \mathrm{~mm}$. reduced and located slightly labially in relation to the protocone. The central area of the occlusal surface bears a mesiodistally elongated and slightly oblique fossa.

The M4 is simplified in relation to M3; it is small $(L=0.87 \mathrm{~mm}$ and $\mathrm{W}=0.71)$ and in occlusal view the crown is roughly triangular (Figures 2.1, 3.3). The labial edge is convex and lacks flexi and cusps. Lingually, there are no proper cusps but the presence of a protocone can be inferred, following the arrangement in the precedent molar. The metaconule is absent. The enamel distribution is irregular; it is absent in the mesiolabial side of the tooth and very thin in the distolingual part. As in other Argyrolagidae, the occlusal surface of M4 is mesioventrally directed, contrasting with the distoventrally orientation of the preceding molar. A subcircular fossa occupies a central position in the occlusal surface.

Lower dentition. The i1 is kidney-shaped (the labial border is convex and the lingual one is concave), labiolingually compressed, procumbent, and deeply implanted (the intraalveolar section extends up to the level of m1) (Figures 3.4-9, 4.1; Table 2). The tooth shows a continuous layer of enamel. In lateral view, the occlusal surface is concave; the mesial side is acute and high, and the distal one is blunt and low. It shows a small and oval fossid near the medial area of the lingual wall.

The second incisor is located immediately behind i1 (Figure 3.6-7). It is smaller and oval in outline. Although hypsodont, this tooth is not deeply implanted since the length of its alveolus is ventrally limited by the alveolus of i1. In lateral view, the crown is mesially orientated. In contrast to $\mathrm{i} 1$, i2 is surrounded by a thick layer of cementum. The occlusal surface presents a well-developed wear facet facing labially.

The third premolar is not preserved in any of the specimens of Microtragulus bolivianus here studied. Its alveolus is separated from i2 by a short diastema, whose mesiodistal length is about the same length of the alveolus of i2. The alveolar size and shape suggest that this tooth was markedly smaller than the first molar (as in other argyrolagids) and not deeply implanted (Figure 4.2-3).

All the lower molars are euhypsodont. The enamel distribution is mostly continuous around the tooth, with small interruptions in the mesial and distal edges of m1-3 (and a small portion of the mesial edge of $\mathrm{m} 4$ ), and the ectoflexid of all molars. Additionally, the layer of enamel of the mesial side of $\mathrm{m} 2$ and $\mathrm{m} 3$ can be absent or be very thin. The cementum has an irregular arrangement. 
TABLE 2. Measurements of the lower dentition of Microtragulus bolivianus (in $\mathrm{mm}$ ). * Measures taken from Hoffstetter and Villarroel (1974).

\begin{tabular}{|c|c|c|c|c|c|c|c|c|c|c|c|c|c|c|}
\hline & \multicolumn{2}{|c|}{ i1 } & \multicolumn{2}{|c|}{ i2 } & \multicolumn{2}{|c|}{ m1 } & \multicolumn{2}{|c|}{ m2 } & \multicolumn{2}{|c|}{ m3 } & \multicolumn{2}{|c|}{$\mathrm{m4}$} & \multirow{2}{*}{$\frac{\mathrm{m} 1-\mathrm{m} 4}{\mathrm{~L}}$} & \multirow{2}{*}{$\frac{\text { i1-m4 }}{L}$} \\
\hline & $\mathbf{L}$ & $\mathbf{W}$ & $\mathbf{L}$ & $\mathbf{W}$ & $\mathbf{L}$ & $\mathbf{W}$ & $\mathbf{L}$ & $\mathbf{W}$ & $\mathbf{L}$ & $\mathbf{W}$ & $\mathbf{L}$ & $\mathbf{W}$ & & \\
\hline Holotype* & 1.3 & 0.6 & - & - & - & - & - & - & 1.5 & 1.3 & 1.4 & 1.0 & - & 10.3 \\
\hline JUY-P-0066 & 1.35 & 0.59 & - & - & 1.50 & 1.14 & 1.53 & 1.49 & 1.44 & 1.34 & 1.14 & 1.08 & 5.77 & 11.01 \\
\hline JUY-P-0067 & 1.66 & 0.70 & 0.92 & 0.63 & 1.68 & 1.27 & 1.88 & 1.61 & 1.68 & 1.47 & 1.49 & 1.19 & 6.44 & 12.50 \\
\hline
\end{tabular}

In most cases, it is thicker in the deepest portion of the ectoflexid and in the labial wall of the talonid. The central fossid is mesiodistally elongated (Figures 2, 4.2-3).

The first molar shows a distinct ectoflexid, which separates the trigonid from the talonid. The entoflexid is absent in m1, as in Microtragulus catamarcensis. This trait is present but vestigial in $M$. reigi (Simpson, 1970a) and clearly demarcated in all the other argyrolagids. The metaconid is the dominant cusp; it is a high crest-like structure mesially displaced; slightly posterior, the lingual wall of the tooth exhibits a tiny bulge that could be an accessory cusp (entostylid?; see Hershkovitz, 1971). The ectostylid is lower and presents a welldeveloped column in the labial wall of the tooth. Mesially, a groove separates this structure from the protoconid which points mesiolabially. The paraconid is absent. The talonid, two thirds shorter than the trigonid, is labiolingually extended with its main axis transversal to the tooth row. It has a distinctive tongue-like hypoconid and a well-developed entoconid. The hypoconulid is a vestigial structure barely distinctive in the distolingual corner of the talonid and adjacent to the entoconid.

The second molar differs from the first one in its larger size, a shallower mesial groove in the trigonid (absent in JUY-P-0066), and a wider ectoflexid. As in $\mathrm{m} 1$, the entoflexid is absent. The hypoconid, entoconid, and hypoconulid have the same development and arrangement than in $\mathrm{m} 1$.

The third molar is shorter than the preceding teeth but longer than $\mathrm{m} 4$. The trigonid is very similar in outline to that of $\mathrm{m} 2$, although both in JUY-P0066 and in JUY-P-0067 the groove mesial to the ectostylid is absent. The talonid is well differentiated in this tooth, since a visible but shallow entoflexid lingually separates these structures. The ectoflexid is very similar to that of $\mathrm{m} 2$. The entoconid is more conspicuous and the hypoconulid is absent. The layer of enamel appears to be reduced in the mesial end of the trigonid in JUY-P-0066 and in the mesial and distolingual edge in JUY-P-0067.
The fourth molar is very different in shape and size from the preceding molars. It is the smallest molar, both in length and width, and the talonid is labiolingually reduced. As in $\mathrm{m} 3$, the trigonid is separated from the talonid by the ecto and entoflexids. The hypoconid is small and low, and the entoconid is a higher crest-like structure. The distal border of the tooth bears a shallow flexid that separates the hypoconid from the distally extended hypoconulid. This arrangement is evident in JUY$\mathrm{P}-0067$ but is masked in JUY-P-0066 given the poor development of the hypoconulid.

Postcranial Skeleton. Among argyrolagids, the postcranium is known from partially preserved remains of Microtragulus argentinus (cuboid, navicular, ectocuneiform, metatarsals III and IV, and caudal vertebrae), M. reigi (humerus, femur, calcaneus, and tibiofibula), and Argyrolagus scagliai (partially preserved vertebrae, scapula, humerus, radius, ulna, pelvic girdle, femur, tibiofibula, tarsals, metatarsals, and phalanges). In addition, an isolated calcaneus (not directly associated to any Anargyrolagus specimen, but coming from the same level and locality; A. Carlini, personal commun., 2016) was recovered at Gaiman, Chubut Province and described by Szalay (1994). Up to now, the anatomical descriptions came from the work of Simpson (1970a), which was focused on $A$. scagliai, $M$. reigi, and $M$. argentinus, and Szalay (1994) who emphasized on the morphology of the Gaiman calcaneus and the crurotarsal joint and tarsal anatomy of Argyrolagus. Here we present a detailed description of isolated pieces of the postcranium of Microtragulus bolivianus, which includes partially preserved humeri, ulnae, radii, tibiofibulae, and complete astragalus, calcaneus, metatarsals, and distal phalanges. According to our observations, there are no significant differences in the morphology of the skeletal pieces among these species. However, in the following section we include several comparisons in order to highlight inter and intraspecific variations. 
Humerus. Four partially preserved humeri (two left and two right) were recovered from the Uquía fossil association (Figure 5.1-16). These elements vary in size and robustness: JUY-P-0070 (Figure 5.5-8) is larger and stouter than the other three humeri, a feature that could be related to sexual or ontogenetic variation. In anterior view the diaphysis is straight. The proximal half of the shaft appears to be twisted in relation to the distal portion although the absence of the head prevents to evaluate clearly this feature. This half bears the deltoid crest. In contrast to the general elongated shape of this structure in many mammals, in argyrolagids (e.g., Microtragulus bolivianus, Argyrolagus) the place of attachment of the M. deltoideus and $\mathrm{M}$. pectoralis major is a short, raised plate-like and ovoid area facing anterolaterally. Laterally, the distal half of the humerus bears a well-developed and hook-shaped ectepicondylar crest, which faces anterolaterally and ends proximally in an acute tip. Even if this crest is not fully preserved, it appears to have a different arrangement in relation to Argyrolagus where it does not flare laterally (Simpson, 1970a). Medially, the distal portion of the diaphysis exhibits a large entepicondylar foramen in which the medial aperture is hidden in anterior view. The same morphology has been described by Simpson (1970a, p. 27) in Argyrolagus scagliai. The distal epiphysis exhibits a rounded capitulum in continuity with an ectepicondyle not expanded laterally. The trochlea is bounded medially by a sharp edge separating it from the entepicondyle. This structure is not medially expanded. The intercondylar notch is deep. Posteriorly, the supratrochlear foramen opens in the supratrochlear fossa which widens medially. Several nutritious foramina pierce the humerus. The medial wall of the entepicondylar foramen bears one (JUY-P-0069), two (JUY-0072), or three (JUY-P-0070, 0071) apertures. Other openings are visible in the proximal edge of the ectepicondylar crest, adjacent to the diaphysis, where the specimens JUY-P-0069 and JUY-P0070 bear one foramen. Finally, foramina are also visible above the posterior side of the supratrochlear foramen (JUY-P-0070, 0071, and 0072 show one aperture and JUY-P-0069 shows two apertures).

Ulna. Two incomplete ulnae were preserved (Figure 5.17-22). The distal end is lost in both elements. The olecranon is short and stout; the anteroposterior length is greater than the proximodistal length. The anconeal process faces laterally and is not part of the anterior border of the olecranon which is well-projected anteriorly. The trochlear notch is deep. The coronoid process is prominent and its articular surface is proximally directed. Distally, the shaft exhibits a concave and triangular area related to the insertion of the $\mathrm{M}$. biceps brachii. The radial notch is concave, facing more laterally, instead of anteriorly. It is well limited posteriorly by an acuminate process. The body is incomplete; nonetheless, it is clear that it narrowed distally. The most conspicuous feature of the shaft is the thinness of the bone and the extremely concave fossa for the M. abductor pollicis longus. This fossa is extended along almost the entire shaft and is limited anteriorly by a sharp crest which is laterally bent in anterior view. In medial view, the proximal third of the ulna exhibits a shallow fossa for the insertion of the M. flexor digitorum profundus.

Radius. The proximal end of a radius is preserved (Figure 5.23). The incompleteness of this element prevents us from determining if it is a right or a left bone. The head is round and the fovea capitis is slightly concave. The neck is conspicuous; it shows a well-developed radial (bicipital) tuberosity, as in Argyrolagus (Simpson, 1970a). The body has a deep posterior fossa probably related with the origin of the M. abductor pollicis longus. Laterally, this fossa is bounded by a sharp pronator crest where the $\mathrm{M}$. pronator teres would be inserted.

Tibiofibula. This complex is represented by a right proximal epiphysis and a fragment of a right distal third. The proximal epiphysis is triangular in proximal view. This area exhibits the medial condyle which is subtriangular and slightly convex; the lateral one is kidney-shaped, concave, and longer anteroposteriorly. The popliteal notch is conspicuous and the intercondylar eminence exhibits both the lateral and medial tuberosities (being the lateral remarkably smaller than the medial one). The extensor sulcus is absent. Anteriorly, the material preserves part of the tibial tuberosity that is a small and smooth surface.

The distal portion of the tibia and the fibula is completely fused (Figure 5.24-25); there is no evidence of sutures distinguishing neither this pair of bones nor the diaphysis from the distal epiphysis. In anterior view this epiphysis exhibits a marked fossa, proximodistally elongated. In posterior view, the shaft has a blunt and oblique longitudinal crest. The tibia bears in its medial face a very shallow notch that indicates the position of the passage of the tendons of the muscles flexing the foot. In turn, the extensor muscles in the lateral side of the fibula pass through a deep groove (Szalay, 1994).

The joint between the tibiofibula and the tarsus includes the articulation with the astragalus 
(medial) and with the calcaneus (lateral). As Szalay (1994) described for Argyrolagus, the crurotarsal joint is highly restricted in Microtragulus; both the fibular and tibial sides contact closely with the astragalus. In addition, the fibular portion joints with a large area in the calcaneus. The astragalotibial facet is formed by two well-differentiated medial and lateral facets. In the same way the medial astragalotibial facet exhibits a horizontal and vertical surface. The horizontal one is concave and anteroposteriorly elongated and the vertical is convex and located in the lateral wall of the medial malleolus. The lateral astragalotibial facet is very convex. On the fibula, the astragalofibular facet is a small surface located in the medial side of the lateral malleolus. This facet is continuous with the lateral astragalotibial facet; therefore, both facets are hard to identify. The calcaneofibular facet is concave, oval, and anteroposteriorly elongated. Its main axis is shorter than the medial astragalotibial facet. Both the morphology of the crurotarsal joint, as well as that of the tarsals is essentially the same in Argyrolagus and Microtragulus.

Astragalus. The astragalar body (corpus tali) is remarkably large; it contrasts with a small head, which occupies one third of the total length of the dorsal face (Figure 6.1-5). In dorsal view the body exhibits the large astragalotibial lateral facet (ATil). It is well extended, both distally and proximally, and is somewhat pulley-like, being the medial half steeper than the lateral one. The astragalar fibular facet is small and the astragalar foramen is absent. The head exhibits the dorsal portion of the astragalonavicular contact, which is proximolaterally-distomedially extended. Medially, this facet shows the astragalar distal tuber. The proximal extension of the lateral tibial contact, the ectal (calcaneoastragalar) facet, and the sustentacular and navicular facets are visible in plantar view. The ectal facet is oval and strongly concave. The main axis is roughly orientated proximomedially-distolaterally. The sustentacular facet is ribbonlike and contacts with the homonymous facet in the calcaneus; it comprises the sustentacular facet properly and the superior sustentacular facet. The first one is formed by two areas, one occupies the central exposition of the plantar face and the other is rodlike and oblique. Both are tangential and its contact is located near the proximomedial end of the rodlike area. The central area of the sustentacular facet is oval, slightly wider distally, and is almost parallel to the ectal facet. The rod-like portion of the sustentacular facet is well exposed in plantar view. It is remarkably convex, and occupies the full width of the astragalar head. A deep and narrow astragalar sulcus (interarticular sulcus) separates this facet from the calcaneoastragalar articulation. The superior sustentacular facet is represented as a deep sulcus between the plantar extension of the astragalotibial lateral facet and the sustentacular facets. The astragalar distal tuber is small and is restricted to the proximomedial portion of the plantar aspect. The astragalonavicular facet is restricted to the distolateral extremity of the head.

In medial view the dominant structure is the semicircular astragalotibial medial facet, clearly defined by a blunt dorsal edge. On the proximal and plantar corner there is a small astragalar medial plantar tuberosity located adjacent to the superior sustentacular facet. Distally this aspect exhibits the medial extension of the contact with the navicular and the astragalar distal tuber. In lateral view the astragalus exhibits the astragalofibular facet which is small, triangular, and faces laterally. The distinctive feature of the distal view is the astragalonavicular joint, which covers almost the entire surface of the head; there is no articulation between the astragalus and the cuboid.

Calcaneus. The tuber is a cylindrical lateromedially compressed structure which widens toward its posterior end (Figure 6.6-10). This end exhibits two smooth surfaces separated by a low step; one is mainly posterior and the other is more plantarly directed. In lateroplantar view the tuber shows an oval scar which was probably related to with the attachment of the M. abductor digiti quinti. A blunt crest runs anteroposteriorly in plantar view and ends in a small anterior plantar tubercle. The peroneal process is located in the laterodistal corner of the plantar aspect. This process is rounded and well developed. Adjacent to the peroneal process, and distal to it, there is a small groove for the M. peroneus longus.

The body of the calcaneus is wide and much shorter than the tuber. In dorsal view the body shows the proximal process bearing the calcaneoastragalar (or ectal) facet and the calcaneofibular facet. Both facets are separated by a shallow groove in Argyrolagus and Microtragulus, differing from the Gaiman calcaneus in which they are close together (see Szalay, 1994, figure 7.28 A, C). The calcaneoastragalar facet faces dorsally and dorsomedially and is smaller and more dorsally projected than the calcaneofibular facet (particularly visible in medial and distal views). Both in Argyrolagus as in Microtragulus, the calcaneoastragalar facet is smaller than that of the Miocene Gaiman calcaneus (Szalay, 1994). The sustentacular facet 
comprises the sustentacular facet properly and the superior sustentacular articulation. As in the astragalus, the sustentacular is divided in two portions: one is proximal, oval, and distally oriented and the other is more distally located, smaller, and faces dorsomedially. The superior sustentacular facet is a small articular surface restricted to the dorsal border of the proximal part of the sustentacular facet. In distal view, this facet is smaller in Argyrolagus than in the Gaiman calcaneus (Szalay, 1994), a condition also present in Microtragulus.

The contact with the cuboid is formed by two discontinuous facets separated by a step. The proximal facet (CaCup) is smaller and somewhat triangular; the distal one (CaCud) is dorsoplantarly elongated and oval.

Metatarsals. One complete right Mt III and three fragments of the Mt IV were recovered (Figure 7.12). The Mt III measures $29.87 \mathrm{~mm}$, slightly larger than Microtragulus argentinus $(27 \mathrm{~mm}$; Ameghino, 1904) and smaller than Argyrolagus scagliai (35.6 mm; Simpson, 1970a, p. 68). The Mt III exhibits a slightly concave T-shaped facet for the articulation with the ectocuneiform. Laterally a marked notch lodges a medial process for the Mt IV; medially, there is a distinctive facet which is interpreted as the contact with a vestigial Mt II, as proposed for Argyrolagus (Simpson, 1970a, figure 15E). The proximal end of the Mt IV exhibits a triangular convex surface which articulates with the cuboid. Laterally this bone presents a proximally projected process that probably covered partially the lateral side of the cuboid, as in Microtragulus argentinus MACN 12925 and Argyrolagus scagliai MMP 785S (Simpson, 1970a). The only peculiarity of the diaphysis of the metatarsals is the flattened area of contact between Mt III and IV. In this last bone, the distal half of the diaphysis is thinner than in Mt III. The distal end of the metatarsals is simple. In the dorsal aspect of the head the articular surface is condylar; in plantar view this structure shows a notorious longitudinal crest.

Phalanges. Three ungual phalanges were recovered (Figure 7.3-5). They are long, slightly curved, and lateromedially compressed. The flexor tubercle is long, constricted in the middle portion, and is pierced by the ungual foramen. The articular facet is strongly concave; the dorsal border is more posteriorly projected than the ventral one.

\section{Comparison}

When compared with Oligocene and Miocene argyrolagids (Proargyrolagus, Hondalagus, and Anargyrolagus), Microtragulus bolivianus shows clear differences involving several features. Regarding Proargyrolagus, the main dental differences include the degree of hypsodonty, the morphology of the occlusal surface, and the dental formula. In Proargyrolagus the molars are hypsodont but rooted (i.e., high crown, not evergrowing; Wolf, 1984; protohypsodont in Goin and Abello, 2013) while in $M$. bolivianus the molars are euhypsodont (i.e., high crown and rootless; Hoffstetter and Villarroel, 1974). The occlusal surface of the upper molars in Proargyrolagus exhibits a complex outline including several distinctive cups and structures (e.g., mesiolabial lobe, paracone + StB, metacone + StD, protocone, and metaconule). In $M$. bolivianus this pattern is simplified with most of the occlusal features largely masked. Another distinctive feature of $M$. bolivianus regarding Proargyrolagus is related to the crown implantation in M34. In Proargyrolagus the crowns of both molars present an almost parallel implantation, while in $M$. bolivianus the intraalveolar part of the crowns is strongly divergent. This divergence determines that the occlusal surface of M3 faces ventrally and that of M4 faces mesioventrally. These differences in implantation are also visible in the lower molars. Additionally, $M$. bolivianus also lacks several dental pieces compared to Proargyrolagus (dental formula 2.0.1.4 for $M$. bolivianus and 3.1.2.4 or 4.0.2.4 for P. bolivianus; see Sánchez-Villagra and Kay [1997] for different interpretations on the lower dental formula in the Oligocene species). Finally, the euhypsodont nature of the lower molars in $M$. bolivianus also determines that the height of the mandibular body is greater in this species.

The upper teeth of the Miocene genus Hondalagus differ mainly in size (smaller in relation to Microtragulus bolivianus), outline (more transverse in Hondalagus), and the distinctive layer of cementum (Sánchez-Villagra et al., 2000), which is much thinner in $M$. bolivianus. Hondalagus has an extra anterior lower tooth (Sánchez-Villagra et al., 2000), a well-developed entoflexid in $\mathrm{m} 1$ and $\mathrm{m} 2$ (absent in M. bolivianus), and proportionally larger talonids (particularly in m4).

The dental formula is the main difference between Anargyrolagus and Microtragulus bolivianus, since the former presents a canine and two more premolars than Microtragulus. In Anargyrolagus M3 is more quadrangular, with a well-developed metaconule, and M4 shows a marked occlusal relief in contrast with $M$. bolivianus, which presents an almost flat occlusal surface. The first lower incisors show a clear fossettid near the medial area of the lingual wall in $M$. bolivianus, 
1

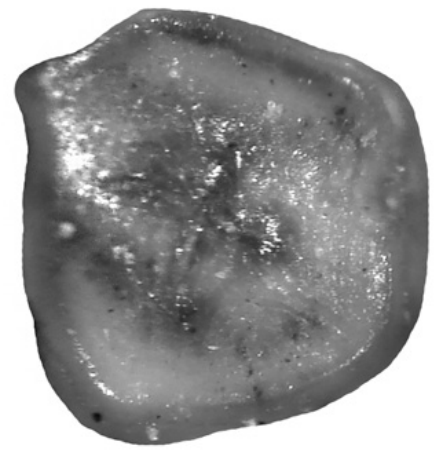

2

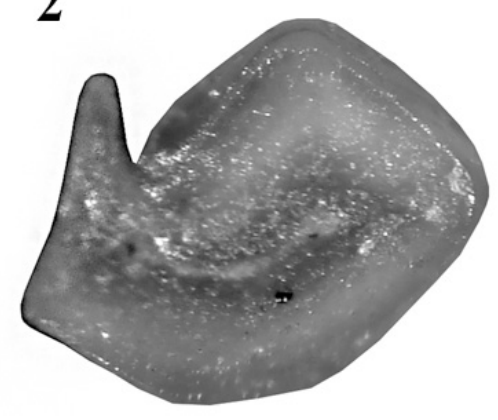

FIGURE 8. Microtragulus sp., upper and lower molars in occlusal views. 1. JUY-P 53, isolated left M3. 2. JUY-P 54, isolated left $\mathrm{m} 2$ or $\mathrm{m} 3$. Scale bar equals $2 \mathrm{~mm}$.

absent in Anargyrolagus. This genus also contrasts with $M$. bolivianus by the higher mandibular body, the well-developed entoflexid and proportionally larger talonid in all the molars, and a proportionally larger m4.

Regarding the genus Argyrolagus, which includes four species ( $A$. scagliai, $A$. parodii, $A$. palmeri, and $A$. rusconii), the upper dentition will be compared only with $A$. scagliai and $A$. rusconii since $A$. parodii and $A$. palmeri are represented only by lower teeth. These two species show M3 longer than wide, with the paracone present and well separated from the metacone, the occlusal outline with more distinctive corners and welldefined angles (especially in the protocone area), and the mesial border much wider than the distal one; all these features represent clear differences regarding $M$. bolivianus. Additionally, the labial wall in both species is straight in M3, contrasting with the convex wall of $M$. bolivianus. Regarding M4, in $A$. scagliai and $A$. rusconii this molar is proportionally larger and both the paracone and metacone are distinctive. Finally, the lower molars of all the species of Argyrolagus are characterized by a visible entoflexid (in m1-m4) and a larger talonid in all molars, particularly in $\mathrm{m} 4$.

The new material of Microtragulus bolivianus described herein can be compared more precisely with the specimens known for $M$. reigi and $M$. catamarcensis. In M. reigi, M3 is longer than wide, while in $M$. bolivianus the ratio between the length and the width is approximately one. Moreover, M3 in $M$. reigi has a small paracone and sharp corners (i.e., a more angled outline). Additionally, the flexus between the mesiolabial lobe and the metacone, present in $M$. bolivianus, is absent in $M$. reigi; the mesial border of the tooth is wider than the distal one; and the layer of cementum is thicker in $M$. reigi. The relative size and shape of M4 is similar between these species, but the presence of differentiated paracone and metacone in $M$. reigi is not observed in $M$. bolivianus. In the lower dentition, the morphology of the incisors is similar in both species. The molars differ in the presence of a small but distinctive entoflexid in m2-3 in $M$. reigi, and a more reduced talonid in its $\mathrm{m} 4$ which also lacks the distal flexid distinguishable in $M$. bolivianus.

Microtragulus catamarcensis is smaller than $M$. bolivianus, and the diastema between i2 and p3 is relatively shorter. Additionally, the talonid of $\mathrm{m} 3$ lacks the entoflexid, clearly present in $M$. bolivianus. The talonid in $\mathrm{m} 4$ has a simpler morphology in $M$. catamarcensis: the cusps are indistinguishable and the distal flexid present in $M$. bolivianus is absent.

\section{Microtragulus sp. Ameghino, 1904 Figure 8}

Referred Material. JUY-P 53, isolated left M3; JUY-P 54, isolated left $\mathrm{m} 2$ or $\mathrm{m} 3$.

Range and Occurrence. San Roque ( $26^{\circ} 14^{\prime} 32^{\prime \prime}$ $\mathrm{S}$ and $65^{\circ} 21^{\prime} 55^{\prime \prime} \mathrm{W} ; 2940 \mathrm{~m}$ ), $4.4 \mathrm{~km} \mathrm{SSW}$ of Humahuaca town, Humahuaca Department, Jujuy Province, Argentina. Uquía Formation (late Pliocene-early Pleistocene; Marplatan SALMA, probably Vorohuan subage; Ortiz et al., 2012).

Remarks. The isolated upper molar (Figure 8.1) is considered herein an M3. The tooth is subquadrangular and exhibits an irregular central fossa; the mesiolabial border is marked as an angled corner. The area of the metacone is represented by a smooth elevation and the area of the protocone is slightly more differentiated (as a subtle corner) 
than the metaconular zone. The distribution of the enamel is irregular: it is clearly present in the labial wall of the tooth but is absent in the mesial side. The layer of cementum is clearly visible in the lingual and mesiolingual walls. The lower molar (Figure 8.2 ) is characterized by a marked reduction of the talonid, both in length as in width. This condition is similar in Microtragulus catamarcensis although in this species the hypoconid is U-shaped while in the isolated molar it is V-shaped. As in other members of Microtragulus (e.g., M. catamarcensis and $\mathrm{m} 1-2$ of $M$. bolivianus) the entoflexid is absent. The central fossid has the usual shape for Argyrolagidae, which is mesiodistally elongated.

We discard the inclusion of these molars in Microtragulus bolivianus based on their smaller size, the general outline of the upper molar (subcircular in M. bolivianus vs. quadrangular in JUY-P $53)$, the absence of a flexus between the mesiolabial corner and the metacone, and the angled hypoconid in the lower tooth. Nevertheless, the isolated nature and scarcity of this material prevent us from providing a specific designation.

\section{DISCUSSION}

\section{On the Nomenclatural Problems Related to the Family Argyrolagidae and the Genera Microtragulus and Argyrolagus}

Since the erection of the genus and species Microtragulus argentinus by Ameghino (1904) based on postcranial elements, the name of the family Argyrolagidae and the genera Microtragulus and Argyrolagus have been through extensive nomenclatural changes (see Appendix).

The basis of the conflict is that the type and only specimen of Microtragulus argentinus was originally included in the Family Tragulidae (Cetartiodactyla) and is represented only by postcranial elements (cuboid, navicular, and ectocuneiform, metatarsals III and IV, and two anterior caudal vertebrae) which lack diagnostic features (Hoffstetter and Villarroel, 1974). In a latter issue of the same volume, Ameghino (1904) erected the Family Argyrolagidae, which he included in Lagomorpha, and the species Argyrolagus palmeri, represented by a left mandibular fragment with $\mathrm{m} 1-\mathrm{m} 4$. This material comes from the same locality and formation than $M$. argentinus (Monte Hermoso Formation, Monte Hermoso locality, Buenos Aires), although the stratigraphical correspondence cannot be ascertained since these data remain unknown for the holotypes of $M$. argentinus and $A$. palmeri. The probability that the types of $M$. argentinus and $A$. palmeri pertain to the same species was initially noted by Carlos Ameghino and Rusconi (see Rusconi, 1936, p. 181).

After the work of Ameghino, some authors focused on this nomenclatural issue and suggested the synonymy and priority of Microtragulus over Argyrolagus (Rusconi, 1936) and even attempted to establish the use of Microtragulidae as the valid name for the family (Reig, 1955). Nevertheless, it was not until 1970 when these successive modifications were extensively and systematically reviewed by Simpson. This author proposed a conservative and arbitrary, though practical, taxonomic scheme. Based on a more complete specimen collection, he found two cranial/dental morphotypes varying in form and size. The larger morphotype included the Argyrolagus species ( $A$. palmeri, $A$. parodii, and the then new $A$. scagliai) and, since the metatarsals assigned to $M$. argentinus are $25 \%$ smaller than those of $A$. scagliai, Simpson decided to maintain the name Microtragulus and associate the smaller tooth morphotypes ( $M$. catamarcensis and the then new $M$. reigi) to this genus. The association was explained by the similar estimated metatarsal length of $M$. reigi (based on the metatarsal lenght/ m1-m4 length ratio of $A$. scagliai), and the known measurement of $M$. argentinus. This proposal was widely accepted, although some authors continued using the name Microtragulidae (e.g., Tonni et al., 1992; Cione and Tonni, 1995; Vizcaíno et al., 2004).

By the time of his contribution, Simpson suspected that the only way to resolve the possible synonymy between the two Monte Hermoso genera was to recover associated metatarsal bones "clearly referable to Microtragulus argentinus and a mandible of the same individual" (Simpson, 1970a, p. 4-5). However, we now realize that this fact would be hardly the solution. As is shown in the taxonomic description above, with the exception of size, there is almost no morphological variation among the comparable postcranial elements of $M$. bolivianus and $M$. argentinus (i.e., metatarsal and tarsal bones), and M. bolivianus and Argyrolagus scagliai. Moreover, the size differences can be obviously associated to intraspecific variability, as has been reported for other species of similar size and ecological requirements (see Nader, 1978).

In this sense, we support the idea that the metatarsals referred to Microtragulus argentinus correspond to Argyrolagus palmeri and agree with the following arguments previously proposed by Hoffstetter and Villarroel (1974, p. 1947): a) the 
specimens referred to these taxa are the only pieces coming from the Monte Hermoso clefts; $b$ ) the metatarsal bones do not exhibit intraspecific morphological variation among argyrolagids; and c) the metatarsal length known and estimated for the metatarsals of $M$. argentinus and $A$. palmeri can be explained by intraspecific variation. In relation to argument a), the Monte Hermoso fauna is currently one of the best studied fauna of Argentina. In the last 50 years, extensive fieldwork and different studies have focused on the resolution of this mammal age, including its mammal diversity, age, and sedimentology (Cione and Tonni, 1995, 2005; Deschamps et al., 2012; Tomassini et al., 2013 and literature therein). In this lapse, two additional specimens were found and referred to $A$. palmeri (Tomassini et al., 2013) and no specimens of a smaller morphotype referable to Microtragulus were found.

At this point, the two conflicts derived from this context are the validity of the name Argyrolagus and thus, the use of Argyrolagidae or Microtragulidae as the family name. The decision to maintain Argyrolagidae (and thus, Argyrolagus as type genus for the family) is supported by Article 64 of the International Code of Zoological Nomenclature (ICZN, 1999). Nevertheless, this fact would only be possible if the synonymy between Microtragulus and Argyrolagus is discarded and both generic names considered valid. This is, according to Simpson (1970a) and in our view, the most recommended scenario, since any other option would require more complicated, controversial, and hardly acceptable actions.

\section{Anatomical Singularities of the Dentary of Argyrolagids}

The dentary of argyrolagids is characterized by a high mandibular body, the presence of two to three dental foramina, an unfused mandibular symphysis extended to the level of $\mathrm{m} 1$ or $\mathrm{m} 2$, the presence of small pits and fenestrations mainly located in the posterior half of the medial side of the dentary, a robust and anteroventrally projected coronoid crest, a low and short coronoid process bearing a masseteric foramen, a well-expanded posterior shelf of the masseteric fossa and angular process, a low condyle placed above the tooth row, and other peculiar features such as a markedly long mandibular notch (ventral end of the posterior border of the coronoid process), and the presence of retromolar foramina and a maxillary canal (Rusconi, 1933, 1936; Simpson, 1970a; Hoffstetter and Villarroel, 1974; Sanchez-Villagra et al., 2000, San-
chez-Villagra, 2001; Goin and Abello, 2013). Some of these traits exhibit intrageneric variation among the basal Deseadan, Miocene, and Pliocene taxa. In Proargyrolagus bolivianus the mandibular body is lower than in the more recent types (Wolf, 1984; Sánchez-Villagra and Kay, 1997), probably in association with the protohypsodont condition of the molars (Wolf, 1984). The coronoid crest is longer in Proargyrolagus and Hondalagus, almost reaching the ventral border of the mandible (judging by the images from Sánchez-Villagra et al., 2000, figure 4a, c). In Anargyrolagus, Argyrolagus, and Microtragulus this crest shortens dorsoventrally but projects more anteriorly, towards the level of the limit between m3-m4. There is also variation among these taxa; for example, in Argyrolagus parodii it is stronger than in $M$. bolivianus.

Posterior and dorsal to the retromolar space the dentary of argyrolagids exhibits some noticeable traits. At the level of the alveolar border the coronoid crest expands and forms a lateral lamina (as described by Simpson, 1970a), which limits the retromolar fossa. Small foramina open in the posterior end of this concavity, clearly visible in Anargyrolagus (Goin and Abello, 2013, figure 4.17), Argyrolagus scagliai (Simpson, 1970a), A. palmeri (Kraglievich, 1931), A. parodii (Rusconi, 1933), and Microtragulus bolivianus (Hoffstetter and Villarroel, 1974; this paper). These openings, called the retromolar foramina, are also present in some groups of mammals such as abderitids (Rusconi, 1933; Abello and Rubilar-Rogers, 2012, figure 6.4) and humans (Schejtman et al., 1967; Kumar Potu et al., 2014). In modern mammals the retromolar foramina are related with the mandibular canal that carries the inferior alveolar nerve and vessels (Schejtman et al., 1967). Other foramina, probably related with this internal net of canals, are present at the base of the medial and lateral sides of the mandibular ramus.

Another particular trait of the argyrolagid mandible is the presence of a short medially located canal at the base of the coronoid process and posterior to $\mathrm{m} 4$ (Figure 9). This canal is bounded medially by a bridge-like vertical osseous bar and laterally by the mandibular ramus. This structure was observed in Microtragulus bolivianus by Hoffstetter and Villarroel (1974) and named the retrodental canal. In modern mammals (e.g., Lagomorpha) it is called the maxillary canal and is the passage of a vein that connects the inferior alveolar and inferior orbital veins (Wible, 2007). Sánchez-Villagra et al. (2000) misinterpreted this trait as a common feature of Argyrolagidae and the 

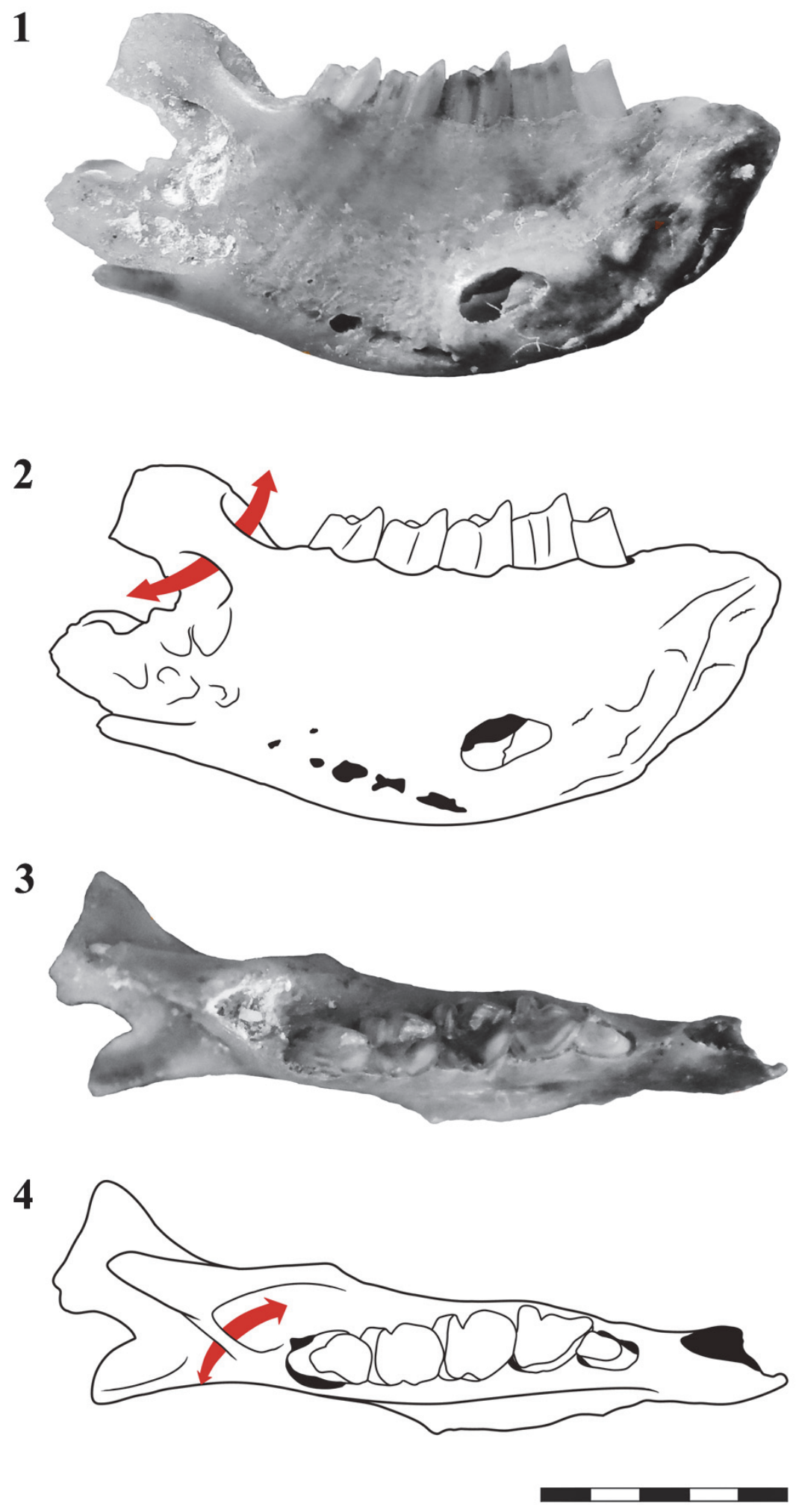

FIGURE 9. Argyrolagus sp. MACN 17590, left mandibular fragment with m1-4. 1-4. Photograph and line drawing in: 1-2, medial; and 3-4, dorsal views. The arrow points the maxillary canal. Scale bar equals $5 \mathrm{~mm}$. 
cenolestid Lestoros but in this genus, as well as in other caenolestids, the canal is actually absent. Therefore, among South American extant and extinct metatherians, the maxillary canal is a unique and singular feature of argyrolagids.

\section{CONCLUSIONS}

This contribution adds new materials to the hypodigm of Microtragulus bolivianus, expanding on several craniomandibular, dental, and postcranial remains. The dental distinctive features of this species include M3 subcircular in outline and with a flexus between the mesiolabial lobe and the metacone (single labial cusp), M4 proportionally smaller than M3 and without differentiated cusp relief, lower molars with talonid proportionally shorter than the trigonid, entoflexid absent in $\mathrm{m} 1$ $\mathrm{m} 2$ and present but shallow in $\mathrm{m} 3$, and talonid in the $\mathrm{m} 4$ proportionally large and with a distinguishable distal flexid.

The cranial and mandibular morphology here evaluated is fairly homogeneous among the Pliocene genera. The mandibular body is short and high, and strongly convex ventrally. Many small vascular openings are scattered over the lateral and medial surface of the body. The number, size, and arrangement of the mental foramina vary among the observed specimens; two to three foramina are variably located in the anterior half of the dentary. The coronoid process is low and short, and the coronoid crest is conspicuous and projects anteroventrally towards the level of the anterior half of $\mathrm{m} 4$. The mandibular condyle is low, placed above the tooth row. A very peculiar feature of the anatomy of the dentary of argyrolagids is the maxillary canal, a structure probable related with the passage of the vein that connected the inferior alveolar and inferior orbital veins and probable analogue to a similar opening found in living Lagomorpha.

After reviewing all available specimens during this study we found the postcranium of argyrolagids to be fairly uniform among members of the family (e.g., Argyrolagus, Microtragulus argentinus, $M$. reigi). Therefore, several skeletal features are not useful enough for taxonomic or phylogenetic studies among Argyrolagidae. This is relevant because the first species included in the family is $M$. argentinus, a taxon founded on postcranial remains. In part because of this situation, the problems related to the validity of the names Argyrolagidae and Microtragulus were questioned repeatedly. At present, this nomenclatural problem has not been formally solved but a reasonable and practical proposal was provided by Simpson (1970a). This option is here considered as the most adequate, and hence, we argue in favor of maintaining the names Argyrolagidae, Microtragulus, and Argyrolagus.

\section{ACKNOWLEDGMENTS}

We thank A. Kramarz and S. Álvarez (MACN), A. Dondas (MMP), M. Reguero (MLP), and A. Abello for access to the collections under their care. Two anonymous reviewers and the editor made valuable comments that greatly improved the paper. The present contribution was supported by the Fundación Miguel Lillo and Facultad de Ciencias Naturales e Instituto Miguel Lillo (Universidad Nacional de Tucumán, Argentina) and the Agencia de Promoción Científica y Tecnológica (FONCyT; PICT 0407).

\section{REFERENCES}

Abello, M.A., Montalvo, C.I., and Goin, F.J. 2002. Marsupiales del Mioceno superior de Caleufú (La Pampa, Argentina). Ameghiniana, 39:433-442.

Abello, M.A. and Rubilar-Rogers, D. 2012. Revisión del género Abderites Ameghino, 1887 (Marsupialia, Paucituberculata). Ameghiniana, 49:164-184.

Ameghino, F. 1897. Mammifères crétaces de l'Argentine. (Deuxième contribution à la connaissance de la faune mammalogique des couches à Pyrotherium). Boletín del Instituto Geográfico Argentino, 18:406521.

Ameghino, F. 1904. Nuevas especies de mamíferos cretáceos y terciarios de la República Argentina. Anales de la Sociedad Científica Argentina, 57:162175, 327-341; 58:35-71, 182-192, 225-291.

Ameghino, F. 1906. Les formations sédimentaires du Crétacé supérieur et du Tertiaire de Patagonie. Anales del Museo Nacional de Buenos Aires, 8:1-586.

Carlini, A.A., Pascual, R., and Goin, F.J. 2007. A new argyrolagid marsupial from the early Miocene of Patagonia. Neues Jahrbuch für Geologie und Paläontologie, 245:323-330.

Cione, A.L., Gasparini, G.M., Soibelzon E., Soibelzon, L.H., and Tonni, E.P. 2015. The Great American Biotic Interchange. A South American Perspective. Springer Briefs in Earth System Sciences Series, South American and Southern Hemisphere. Springer, Netherlands.

Cione, A.L. and Tonni, E.P. 1995. Los estratotipos de los pisos Montehermosense y Chapadmalalense (Plioceno) del esquema cronológico sudamericano. Ameghiniana, 32:369-374.

Cione, A.L. and Tonni, E.P. 2005. Bioestratigrafía basada en mamíferos del Cenozoico superior de la provincia de Buenos Aires, Argentina, p. 183-200. In de Barrio, R.E., Etcheverry, R.O., Caballé, M.F., and Llambías, E. (eds.), Geología y Recursos Minerales de la Pro- 
vincia de Buenos Aires, XVI Congreso Geológico Argentino, La Plata.

de Muizon, C. 1998. Mayulestes ferox, a borhyaenoid (Metatheria, Mammalia) from the Paleocene of Bolivia. Phylogenetic and palaeobiologic implications. Geodiversitas, 20:19-142.

Deschamps, C.M., Vucetich, M.G., Verzi, D.H., and Olivares, A.I. 2012. Biostratigraphy and correlation of the Monte Hermoso Formation (early Pliocene, Argentina): the evidence from caviomorph rodents. Journal of South American Earth Science, 35:1-9.

García-López, D.A. and Babot, M.J. 2015. A late Miocene Argyrolagidae (Mammalia, Metatheria, Bonapartheriiformes) from Northwestern Argentina. Ameghiniana, 52:314-323.

Garrido, A.C., Turazzini, G.F., Bond, M., Aguirrezabala, G., and Forasiepi, A.M. 2014. Estratigrafía, vertebrados fósiles y evolución tectosedimentaria de los depósitos neógenos del Bloque de San Rafael (Mioceno-Plioceno), Mendoza, Argentina. Acta geológica lilloana, 26:133-164.

Goin, F.J. 1995. Los Marsupiales, p. 165-179. In Alberdi, M.A., Leone, G., and Tonni, E.P. (eds.), Evolución Biológica y Climática de la Región Pampeana Durante los Últimos Cinco Millones de Años. Museo Nacional de Ciencias Naturales, Consejo Superior de Investigaciones Científicas, Madrid.

Goin, F.J. and Abello, A. 2013. Los Metatheria sudamericanos de comienzos del Neógeno (Mioceno temprano, Edad Mamífero Colhuehuapense): Microbiotheria y Polydolopimorphia. Ameghiniana, 50:51-78.

Goin F.J., Abello M.A., and Chornogubsky L. 2010. Middle Tertiary marsupials from central Patagonia (early Oligocene of Gran Barranca): understanding South America's Grande Coupure, p. 69-105. In Madden, R.H., Carlini, A.A., Vucetich, M.G., and Kay, R.F. (eds.), The Paleontology of Gran Barranca. Cambridge University Press, Cambridge.

Goin, F.J. and Candela, A. 2004. New Paleogene marsupials from the Amazon Basin of Eastern Perú, p. 1560. In Campbell, K.E. Jr. (ed.), The Paleogene Mammalian Fauna of Santa Rosa, Amazonian Perú. Natural History Museum of Los Angeles County, Sciences Series 40, Los Angeles.

Goin, F.J., Montalvo, C.I., and Visconti, G. 2000. Los marsupiales (Mammalia) del Mioceno superior de la Formación Cerro Azul (provincia de La Pampa, Argentina). Estudios geológicos, 56:101-126.

Hershkovitz, P. 1971. Basic crown patterns and cusp homologies of mammalian teeth, p. 95-150. In Dahlberg, A.A. (ed.), Dental Morphology and Evolution. University of Chicago Press, Chicago.

Hershkovitz, P. 1995. The staggered marsupial lower third incisor: hallmark of cohort Didelphimorphia, and description of a new genus and species with staggered 13 from Albian (Lower Cretaceous) of Texas. Bonner Zoologishe Beitrage, 45:153-169.
Hoffstetter, R. and Villarroel, C. 1974. Découverte d'un marsupial Microtragulidae (Argyrolagidé) dans le Pliocène de l'Altiplano bolivien. Centre de Réchèrches de l'Académie des Sciences, Paris, 278D:1947-1950.

Illiger, C. 1811. Podromus Systematis Mammalium et Avium Additis Terminis Zoographicis Utriudque Classis. C. Salfeld, Berlin.

International Commission on Zoological Nomenclature. 1999. International Code of Zoological Nomenclature (fourth edition). International Trust for Zoological Nomenclature.

Koenigswald, W.V. 2011. Diversity of hypsodont teeth in mammalian dentitions - construction and classification. Palaeontographica Abteilung A: Paläozoology Stratigraphie, 294:63-94.

Kraglievich, L. 1931. Cuatro notas paleontológicas sobre Octomylodon aversus Amegh., Argyrolagus palmeri Amegh., Tetrastylus montanus Amegh., y Muñizia paranensis. Revista de la Sociedad Argentina de Ciencias Naturales, 10:242-266.

Kumar Potu, B., Kumar, V., Salem, A.H., and Abu-Hijleh, M. 2014. Occurrence of the retromolar foramen in dry mandibles of South-Eastern part of India: A morphological study with review of the literature. Anatomy Research International, 2014;2014:296717 doi:10.1155/2014/296717.

MacFadden, B.J., Wang, Y., Cerling, T.E., and Anaya, F. 1994. South American fossil mammals and carbon isotopes: a 25 million-year sequence from the Bolivian Andes. Palaeogeography, Palaeoclimatology, Palaeoecology, 107:257-268.

Marshall, L.G., Swisher III, C.C., Lavenu, A., Hoffstetter, R., and Curtis, G.H. 1992. Geochronology of the mammal-bearing late Cenozoic on the northern Altiplano, Bolivia. Journal of South American Earth Sciences, 5:1-19.

Nader, I.A. 1978. Kangaroo rats: Intraspecific variation in Dipodomys spectabilis Merriam and Dipodomys deserti Stephens. Illinois Biological Monographs, 49:1-116.

Ortiz, P.E., García-López, D.A., Babot, M.J., Pardiñas, U.F.J., Alonso Muruaga, P.J., and Jayat, J.P. 2012. Exceptional Late Pliocene microvertebrate diversity in northwestern Argentina reveals a marked small mammal turnover. Palaeogeography, Palaeoclimatology, Palaeoecology, 361-362:21-37.

Reig, O.A. 1955. Un nuevo género y especie de cenolestinos del Plioceno de la provincia de Buenos Aires (República Argentina). Revista de la Asociación Geológica Argentina, 10:60-71.

Reig, O.A. 1958. Notas para una actualización del conocimiento de la fauna de la Formación Chapadmalal. Acta geológica lilloana, 2:241-253.

Ringuelet, A.B. 1966. Marsupialia, p. 46-59. In Borello, A.V. (ed.), Paleontografía Bonaerense, IV: Paleovertebrata. Comisión de Investigaciones Científicas, Provincia de Buenos Aires, La Plata, Buenos Aires. 
Rovereto, C. 1914. Los estratos araucanos y sus fósiles. Anales del Museo Nacional de Historia Natural, 25:1250.

Rusconi, C. 1933. New Pliocene remains of diprotodont marsupials from Argentina. Journal of Mammalogy, 14:244-250.

Rusconi, C. 1936. La supuesta afinidad de Argyrolagus con los Typotheria. Boletín de la Academia Nacional de Ciencias de Córdoba, 33:173-182.

Rusconi, C. 1967. Animales Extinguidos de Mendoza y de la Argentina. Imprenta Oficial, Mendoza.

Sánchez-Villagra, M.R. 2001. The phylogenetic relationships of argyrolagid marsupials. Zoological Journal of the Linnean Society, 131:481-496.

Sánchez-Villagra, M.R. and Kay, R.F. 1997. A skull of Proargyrolagus, the oldest argyrolagid (Late Oligocene Salla Beds, Bolivia), with brief comments concerning its paleobiology. Journal of Vertebrate Paleontology, 17:717-724.

Sánchez-Villagra, M.R, Kay, R.F., and Anaya-Daza, F. 2000. Cranial anatomy and paleobiology of the Miocene marsupial Hondalagus altiplanensis and a phylogeny of argyrolagids. Palaeontology, 43:287-301.

Schaller, O. 1992. Illustrated Veterinary Anatomical Nomenclature. Ferdinand Enke Verlag, Stuttgart, 575 pp.

Schejtman, R., Devoto, F.C.H., and Arias, N.H. 1967. The origin and distribution of the elements of the human mandibular retromolar canal. Archives of Oral Biology, 12:1261-1267.

Simpson, G.G. 1970a. The Argyrolagidae, extinct South American marsupials. Bulletin of the Museum of Comparative Zoology, 139:1-86.

Simpson, G.G. 1970b. Additions to knowledge of the Argyrolagidae (Mammalia, Marsupialia) from the Late Cenozoic of Argentina. Breviora, 361:1-17.
Szalay, F.S. 1994. Evolutionary History of the Marsupials and an Analysis of Osteological Characters. Cambridge University Press, Cambridge.

Tomassini, R.L., Montalvo, C.I., Deschamps, C., and Manera, T. 2013. Biostratigraphy and biochronology of the Monte Hermoso Formation (early Pliocene) at its type locality, Buenos Aires Province, Argentina. Journal of South American Earth Sciences, 48:31-42.

Tonni, E.P., Prado, J., Fidalgo, F., and Laza, J. 1992. El Piso/Edad Montehermosense (Plioceno) y sus mamíferos. III Jornadas Geológicas Bonaerenses, Actas:13-118.

Villarroel, C. and Marshall, L.G. 1988. A new argyrolagoid (Mammalia: Marsupialia) from the middle Miocene of Bolivia. Journal of Paleontology, 62:463-467.

Vizcaíno, S.F., Fariña, R.A., Zárate, M.A., Bargo, M.S. and Schultz, P. 2004. Palaeoecological implications of the mid-Pliocene faunal turnover in the Pampean Region (Argentina). Palaeogeography, Palaeoclimatology, Palaeoecology, 213:101-113.

Wible, J.R. 2003.On the cranial osteology of the shorttailed opossum Monodelphis brevicaudata (Didelphidae, Marsupialia). Annals of Carnegie Museum, 72:137-202.

Wible, J.R. 2007. On the cranial osteology of the Lagomorpha. Bulletin of Carnegie Museum of Natural History, 39:1-234.

Wolff, R. 1984. A new Early Oligocene Argyrolagoid (Mammalia, Marsupialia) from Salla, Bolivia. Journal of Vertebrate Paleontology, 4:108-113.

Zimicz, N. 2011. Patrones de desgaste y oclusión en el sistema masticatorio de los extintos Argyrolagoidea (Marsupialia, Polydolopimorphia, Bonapartheriiformes). Ameghiniana, 48:358-379. 


\section{APPENDIX}

Revision of the changes that occurred in the last century in the nomenclature of the Family Argyrolagidae and the genera Microtragulus and Argyrolagus.

\begin{tabular}{|c|c|}
\hline $\begin{array}{l}\text { Author and year of publication and erected } \\
\text { family and species or used names }\end{array}$ & Comments \\
\hline $\begin{array}{l}\text { Ameghino, } 1904 \\
\text { Family Tragulidae } \\
\text { Microtragulus argentinus }\end{array}$ & This taxon was founded on the basis of metatarsal and tarsal bones \\
\hline $\begin{array}{l}\text { Ameghino, } 1904 \\
\text { Family Argyrolagidae } \\
\text { Argyrolagus palmeri }\end{array}$ & $\begin{array}{l}\text { A. palmeri is the type species of the genus Argyrolagus. Microtragulus argentinus } \\
\text { and } A \text {. palmeri were published in the same year, but Microtragulus has priority } \\
\text { because was published in an earlier issue of the same volume }\end{array}$ \\
\hline $\begin{array}{l}\text { Kraglievich, } 1931 \\
\text { Family Argyrolagidae } \\
\text { Microtragulus catamarcensis }\end{array}$ & $\begin{array}{l}\text { This author named a small dentary coming from Catamarca Province as } \\
\text { Argyrolagus catamarcensis. Posteriorly Simpson (1970a) proposed the new } \\
\text { combination Microtragulus catamarcensis }\end{array}$ \\
\hline $\begin{array}{l}\text { Rusconi, } 1936 \\
\text { Family Argyrolagidae } \\
\text { Microtragulus = Argyrolagus }\end{array}$ & $\begin{array}{l}\text { This author suggested the synonymy but he did not consider the priority of } \\
\text { Microtragulus under Argyrolagus and continued the use of Argyrolagus and } \\
\text { Argyrolagidae (See also Rusconi, 1967) }\end{array}$ \\
\hline $\begin{array}{l}\text { Reig, 1955, } 1958 \\
\text { Family Microtragulidae } \\
\text { Microtragulus = Argyrolagus }\end{array}$ & $\begin{array}{l}\text { This author established this synonymy after he and Kraglievich studied the then } \\
\text { new specimen referred as Microtragulus sp. (probably the holotype of } \\
\text { Argyrolagus scagliai) and began the use of Microtragulidae with Microtragulus as } \\
\text { the only valid genus }\end{array}$ \\
\hline $\begin{array}{l}\text { Ringuelet, } 1966 \\
\text { Family Microtragulidae } \\
\text { Microtragulus = Argyrolagus } \\
\text { M. argentinus = A. palmeri }\end{array}$ & $\begin{array}{l}\text { This author established the priority of Microtraguidae over Argyrolagidae, } \\
\text { Microtragulus under Argyrolagus, and } M \text {. argentinus under } A \text {. palmeri. The } \\
\text { material there figured (but not catalogued; see p. 58) was referred as } M \text {. } \\
\text { argentinus but later assigned to the neotype of } A \text {. parodii (Simpson, 1970b) and } \\
\text { catalogued as MLP 62-VII-27-81 }\end{array}$ \\
\hline $\begin{array}{l}\text { Simpson, } 1970 \text { a } \\
\text { Family Argyrolagidae } \\
\text { Microtragulus (including M. argentinus, M. } \\
\text { catamarcensis, M. reigi) }\end{array}$ & $\begin{array}{l}\text { This author made the first comprehensive attempt in order to resolve the } \\
\text { nomenclatural problems in the family (see text for a complete explanation) }\end{array}$ \\
\hline $\begin{array}{l}\text { Hoffstetter and Villarroel, } 1974 \\
\text { Family Microtragulidae } \\
\text { Microtragulus (including M. reigi, M. } \\
\text { catamarcensis, and M. bolivianus }\end{array}$ & $\begin{array}{l}\text { They validated the genus Microtragulus (including Argyrolagus) and proposed } \\
\text { tentatively the erection of the subgenus Microtragulus and Argyrolagus. } \\
\text { Microtragulus bolivianusis presented as Microtragulus (Argyrolagus?) bolivianus } \\
\text { in the original publication. The authors did not formalize the taxonomic status of } \\
\text { the genera included in Argyrolagus }\end{array}$ \\
\hline $\begin{array}{l}\text { Tonni et al., } 1992 \\
\text { Family Microtragulidae } \\
\text { Argyrolagus palmeri }\end{array}$ & $\begin{array}{l}\text { These authors included these taxon names in a taxomic list of the mammals } \\
\text { recovered at Monte Hermoso (Buenos Aires) and included in the Montehermosan } \\
\text { SALMA. No explanation was given in relation to the exclusion of } M \text {. argentinus } \\
\text { from this list }\end{array}$ \\
\hline $\begin{array}{l}\text { Cione and Tonni, } 1995 \\
\text { Family Microtragulidae } \\
\text { Microtragulus (including M. reigi) } \\
\text { Argyrolagus (including A. palmeri, A. scagliai) }\end{array}$ & $\begin{array}{l}\text { M. argentinus is not included among the taxa recovered at Monte Hermoso, } \\
\text { Buenos Aires }\end{array}$ \\
\hline $\begin{array}{l}\text { Goin, } 1995 \\
\text { Family Argyrolagidae } \\
\text { Microtragulus (including M. argentinus, } M . \\
\text { reigi) } \\
\text { Argyrolagus (including A. palmeri, A. scagliai) }\end{array}$ & The author followed the proposal of Simpson (1970a) \\
\hline $\begin{array}{l}\text { Vizcaíno et al., } 2004 \\
\text { Family Microtragulidae } \\
\text { Microtragulus reigi } \\
\text { Argyrolagus scagliai }\end{array}$ & The authors followed Tonni et al. (1992) \\
\hline
\end{tabular}


PALAEO-ELECTRONICA.ORG

Author and year of publication and erected family and species or used names

Comments

Sanchez-Villagra, 2001; Goin et al., 2000;

Zimicz, 2011; Ortiz et al., 2012; Goin and

Abello, 2013; Tomassini et al., 2013; García

López and Babot, 2015.

Family Argyrolagidae

Microtragulus (including $M$. argentinus, $M$.

reigi, M. bolivianus)

Argyrolagus (including A. palmeri, A. scagliai) 